\title{
Mechanisms Underlying Spontaneous Action Potential Generation Induced by Catecholamine in Pulmonary Vein Cardiomyocytes: A Simulation Study
}

\author{
Shohei Umehara ${ }^{1}$, Xiaoqiu Tan ${ }^{2}$, Yosuke Okamoto ${ }^{3}$, Kyoichi Ono $^{3}$, Akinori Noma ${ }^{1}$, \\ Akira Amano ${ }^{1}$ and Yukiko Himeno ${ }^{1, * \mathbb{D}}$ \\ 1 Department of Bioinformatics, College of Life Sciences, Ritsumeikan University, Shiga 525-8577, Japan; \\ shoumezoo@gmail.com (S.U.); noma@sk.ritsumei.ac.jp (A.N.); a-amano@fc.ritsumei.ac.jp (A.A.) \\ 2 Institute of Cardiovascular Research, Southwest Medical University, Luzhou 640000, China; \\ tanxiaoqiu@swmu.edu.cn \\ 3 Department of Cell Physiology, Graduate School of Medicine, Akita University, Akita 010-8543, Japan; \\ okamoto@med.akita-u.ac.jp (Y.O.); onok@med.akita-u.ac.jp (K.O.) \\ * Correspondence: hime@fc.ritsumei.ac.jp; Tel.: +81-77-599-4361
}

Received: 11 May 2019; Accepted: 12 June 2019; Published: 14 June 2019

\begin{abstract}
Cardiomyocytes and myocardial sleeves dissociated from pulmonary veins (PVs) potentially generate ectopic automaticity in response to noradrenaline (NA), and thereby trigger atrial fibrillation. We developed a mathematical model of rat PV cardiomyocytes (PVC) based on experimental data that incorporates the microscopic framework of the local control theory of $\mathrm{Ca}^{2+}$ release from the sarcoplasmic reticulum (SR), which can generate rhythmic $\mathrm{Ca}^{2+}$ release (limit cycle revealed by the bifurcation analysis) when total $\mathrm{Ca}^{2+}$ within the cell increased. $\mathrm{Ca}^{2+}$ overload in SR increased resting $\mathrm{Ca}^{2+}$ efflux through the type II inositol 1,4,5-trisphosphate $\left(\mathrm{IP}_{3}\right)$ receptors $\left(\mathrm{InsP}_{3} \mathrm{R}\right)$ as well as ryanodine receptors (RyRs), which finally triggered massive $\mathrm{Ca}^{2+}$ release through activation of RyRs via local $\mathrm{Ca}^{2+}$ accumulation in the vicinity of RyRs. The new PVC model exhibited a resting potential of $-68 \mathrm{mV}$. Under NA effects, repetitive $\mathrm{Ca}^{2+}$ release from SR triggered spontaneous action potentials (APs) by evoking transient depolarizations (TDs) through $\mathrm{Na}^{+} / \mathrm{Ca}^{2+}$ exchanger $\left(\mathrm{AP}_{\mathrm{TD}} \mathrm{s}\right)$. Marked and variable latencies initiating $\mathrm{AP}_{\mathrm{TDS}}$ could be explained by the time courses of the $\alpha 1$ - and $\beta 1$-adrenergic influence on the regulation of intracellular $\mathrm{Ca}^{2+}$ content and random occurrences of spontaneous $\mathrm{TD}$ activating the first $\mathrm{AP} \mathrm{P}_{\mathrm{TD}}$. Positive and negative feedback relations were clarified under $\mathrm{AP}_{\mathrm{TD}}$ generation.
\end{abstract}

Keywords: rat pulmonary vein cardiac myocyte; automaticity; $\alpha 1$ - and $\beta 1$-adrenoceptor; $\operatorname{InsP}_{3} \mathrm{R} ; \mathrm{IP}_{3}$

\section{Introduction}

Several types of atrial fibrillation may be attributed to the ectopic activity of myocardial cells in the sleeves of pulmonary vein cardiomyocytes (PVCs) under augmented sympathetic stimulation [1-6]. Supporting this hypothesis, electrophysiological and histochemical experiments of rat PVCs by Okamoto et al. demonstrated generations of spontaneous action potentials under the influence of noradrenaline (NA) in dissociated PVCs $[7,8]$ as observed in the tissue preparations [9].

The arrhythmogenic influencing of the stimulation of the $\alpha 1$-adrenergic receptor (AR) has been extensively studied in atrial cardiac myocytes $[10,11]$. These studies have indicated the functional significance of the co-localization of type II inositol 1,4,5-trisphosphate $\left(\mathrm{IP}_{3}\right)$ receptors $\left(\mathrm{InsP}_{3} \mathrm{Rs}\right)$ with type II ryanodine receptors (RyRs). The $\mathrm{Ca}^{2+}$ release through $\mathrm{InsP}_{3} \mathrm{Rs}$ from the sarcoplasmic reticulum (SR) was suggested to directly evoke a larger $\mathrm{Ca}^{2+}$ release via RyRs to initiate $\mathrm{Ca}^{2+}$ sparks. If multiple $\mathrm{Ca}^{2+}$ sparks overlap others, the resultant $\mathrm{Ca}^{2+}$ transient can trigger the temporal depolarization (TD) 
of the resting membrane through the $\mathrm{Na}^{+} / \mathrm{Ca}^{2+}$ exchanger (NCX), thereby triggering action potentials $\left(\mathrm{AP}_{\mathrm{TD}} \mathrm{s}\right)$. Co-immunostaining of atrial myocytes with antibodies against type II RyRs and type II $\mathrm{InsP}_{3} \mathrm{Rs}$ revealed that they were localized on the SR membrane facing the subsarcolemmal space. This coupling of $\mathrm{InsP}_{3} \mathrm{R}$ with RyR has scarcely been observed in the free running network of SR, where RyRs are expressed at a lower density. Thus, the excitation-contraction $(\mathrm{E}-\mathrm{C})$ coupling in atrial myocytes may be activated if InsP $\mathrm{P}_{3} \mathrm{R}$ is activated by the $\alpha 1-\mathrm{AR}$ stimulation. Spontaneous TD might occur at the junction of the SR terminal cisterna with the cell surface membrane in atrial myocytes.

In contrast to atrial myocytes, the E-C coupling in ventricular myocytes mostly occurs at the dyadic junction all over the cell, but the density of the $\operatorname{Ins}_{3} \mathrm{R}$ expression is much lower than that in the atrial myocytes [10]. The density of the distribution of RyRs in ventricular myocytes is much higher than in the atrial myocytes. Therefore, the probability of direct coupling of RyRs with $\mathrm{InsP}_{3} \mathrm{R}$ might be expected to be much less in ventricular myocytes, where the enhancement of TD is barely evoked by the $\alpha 1$-AR stimulation.

The PVCs in the sleeves of pulmonary veins are comparable in size and shape to ventricular myocytes and have a regular sarcomere pattern. The localization of Ins $\mathrm{P}_{3} \mathrm{Rs}$ was demonstrated to be parallel to the sarcomere pattern at a high density by Okamoto et al. [7]. They also demonstrated that the noradrenaline (NA) stimulation evoked a train of $\mathrm{AP}_{\mathrm{TD}}$ discharge and that the resting membrane potential showed sporadic micro-fluctuations even in the absence of adrenergic stimulation.

Although different cell types might be involved in the arrhythmogenic activity in the pulmonary vein in different species [3], we focused on a particular cell type, which has been well characterized in a rat pulmonary vein $[7,8]$. We examined mechanisms underlying the generation of a train of spontaneous $\mathrm{AP}_{\mathrm{TD}} \mathrm{s}$ in response to NA stimulation by developing a mathematical PVC model. Until now, mathematical modeling of PVC has only been completed in humans [12] and rabbits [13], both of which showed automaticity in the absence of NA stimulation. Conversely, neither cardiomyocytes nor tissue preparation in PVs exhibited automaticity in rats [7,9]. To understand the mechanisms underlying the automaticity induced by NA stimulation by involving mobilization of intracellular $\mathrm{Ca}^{2+}$ as suggested by Okamoto et al., we used a refined model of the $\mathrm{Ca}^{2+}$-induced $\mathrm{Ca}^{2+}$ release (CICR) mechanisms, which was developed based on the Hinch model of $\mathrm{Ca}^{2+}$ releasing unit CaRU $[14,15]$ and was adjusted to the human ventricular cell (HuVEC) model [16]. The novel CICR model was adopted in our study in combination with the $\mathrm{InsP}_{3} \mathrm{R}$ model. The desensitization of the response to continuous $\alpha 1-\mathrm{AR}$ stimulation [17] and $\beta 1$-AR stimulation [18] were defined by empirical equations. The simulation results showed that the arrhythmogenic activity (spontaneous generation of repetitive $\mathrm{AP}_{\mathrm{TD}}$ ) of PVCs could be initiated when variable conditions are combined in addition to the close coupling of InsP $\mathrm{P}_{3} \mathrm{R}$ and RyR. The pivotal additional factor is the activation of the $\beta 1-\mathrm{AR}$ receptor to increase the $\mathrm{Ca}^{2+}$ store within SR $\left(\mathrm{Ca}^{2+}\right.$ overload) through enhancement of both L-type $\mathrm{Ca}^{2+}$ channel (LCC) and sarcoplasmic/endoplasmic reticulum calcium pump (SERCA). The whole cell simulation of the PVC model suggests that $\mathrm{Ca}^{2+}$ extrusion by NCX, the temporal $\mathrm{Ca}^{2+}$ accumulation near the $\mathrm{Ca}^{2+}$ releasing site within the cytosol, and a $\mathrm{Ca}^{2+}$ overload of the SR are also essential in evoking spontaneous $\mathrm{AP}_{\mathrm{TD}}$ in the PVCs.

\section{Results}

\subsection{Intracellular $\mathrm{Ca}^{2+}$ Dynamics Revealed by Bifurcation Analyses}

Experimental studies have established that spontaneous $\mathrm{Ca}^{2+}$ release from SR occurs, and the $\mathrm{Ca}^{2+}$ transient evokes TD through the activation of NCX if the cardiac myocyte is overloaded with $\mathrm{Ca}^{2+}$ [19-22]. These cytosolic $\mathrm{Ca}^{2+}$ oscillations are important because they are accompanied by spontaneous oscillations in current and membrane potential to produce action potentials [23]. To clarify the behavioral characteristics of the cytosolic $\left[\mathrm{Ca}^{2+}\right]$ in our PVC model, we examined steady-state solutions in the minimal model of intracellular $\mathrm{Ca}^{2+}$ dynamics. The constituents of this minimal model are described in Section 4. In short, we removed all the current systems on the plasma membrane from 
the PVC model to focus on the oscillatory behavior of intracellular $\mathrm{Ca}^{2+}$. To this minimal model, we applied bifurcation analyses, which have been successfully used to identify equilibrium points and/or the stable limit cycle in the mathematical whole cell or reduced models [24-26].

Firstly, we fixed the total $\mathrm{Ca}^{2+}$ content $\left(\mathrm{Ca}_{\text {tot }}\right)$ within a cell at a control level (3.20 femtomole) and found that the system was stable at a Catot at junction space $\left(j n c ;\left[\mathrm{Ca}^{2+}{ }_{\text {tot }}\right]_{j n c}\right)$ of $0.143 \mathrm{mM}$. The stable point was on the red curve on the left in Figure 1A (upper panel). Then, the amount of total $\mathrm{Ca}^{2+}$ was used as a bifurcation parameter and increased from 3.20 to 7.20 femtomole. The result shown in Figure $1 \mathrm{~A}$ revealed that the system diverged at $\mathrm{Ca}_{\text {tot }}=4.180$ femtomole. When $\mathrm{Ca}_{\text {tot }}$ increased over the diversion point in the range of 4.180 to 5.923 femtomole, stable limit cycles (green) appeared with unstable equilibrium points (black). These results indicate that cyclic $\mathrm{Ca}^{2+}$ release occurred when $\mathrm{Ca}_{\text {tot }}$ was in the range plotted in green. In the usual numerical integration simulation, the peak and bottom level of the $\mathrm{Ca}^{2+}$ transients agreed well with the upper and lower level of the limit cycle depicted in green. As the $\alpha 1$-AR stimulation is mediated by the $\operatorname{Ins}_{3} \mathrm{R}$, its open probability of the channel ( $\mathrm{pO}_{\mathrm{InsP} 3 \mathrm{R}}$ ) was used as a bifurcation parameter in Figure 1B. Catot was fixed at 3.6 femtomole for this analysis. At this low $\mathrm{Ca}_{\text {tot }}$ level, a stable equilibrium resting $\left[\mathrm{Ca}_{\text {tot }}\right]_{j n c}=0.178 \mathrm{mM}$ was observed. When $\mathrm{pO}_{\mathrm{Ins} P 3 \mathrm{R}}$ increased, stable limit cycles were evoked between $\mathrm{pO}_{\text {InsP3R }} 0.0047$ and 0.067. Increasing $\mathrm{PO}_{\mathrm{Ins} P 3 \mathrm{R}}$ induced stable limit cycles at a $\mathrm{Ca}_{\text {tot }}$ level at which the system was stable without $\mathrm{Ins}_{3} \mathrm{R}$ activation, and vice versa, increasing $\mathrm{Ca}_{\text {tot }}$ induced stable limit cycles even when there was no $\mathrm{InsP}_{3} \mathrm{R}$ activation in this system. As is evident from the lower panels in Figure 1, the frequency of the automaticity increased markedly with increasing $\mathrm{Ca}_{\text {tot }}$ or $\mathrm{PO}_{\text {InsP3R }}$.
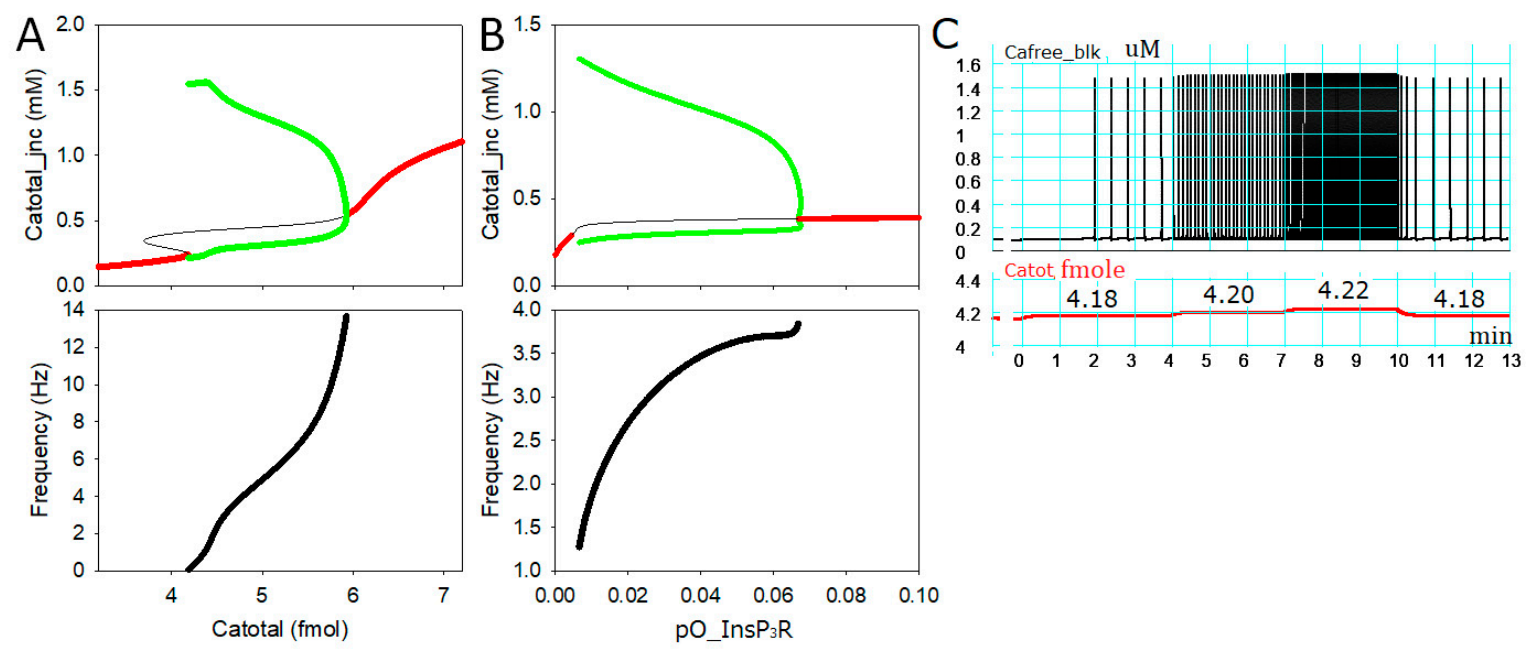

Figure 1. Bifurcation diagrams of the $\mathrm{Ca}^{2+}$ dynamics model: (A) A bifurcation diagram with the total $\mathrm{Ca}^{2+}$ content within the cell on the abscissa and total amount of $\mathrm{Ca}^{2+}$ within the junction space (jnc; $\left[\mathrm{Ca}^{2+}{ }_{\text {tot }}\right]_{j n c}$ ) on the ordinate (upper) and the corresponding frequency is shown with the same parameter as in the upper panel on the abscissa (bottom); (B) a bifurcation diagram with the open probability of type II inositol 1,4,5-trisphosphate receptors ( $\left.\mathrm{pO}_{-} \mathrm{InsP}_{3} \mathrm{R}\right)$ on the abscissa and total amount of $\mathrm{Ca}^{2+}$ within the $j n c\left(\left[\mathrm{Ca}^{2+}{ }_{\text {tot }}\right]_{j n c}\right)$ on the ordinate (upper) and the corresponding frequency is shown with the same parameter as in the upper panel on the abscissa (bottom). Stable equilibrium points, unstable equilibrium points and stable limit cycles were plotted in red, black and green respectively in the upper panels of $\mathrm{A}$ and $\mathrm{B} ;(\mathrm{C})$ results of time integration calculated using the same $\mathrm{Ca}^{2+}$ dynamics model as in (A). Catot was changed as indicated in the lower panel in (C), and the spontaneous frequency was $0.04,0.16$, and $0.29 \mathrm{~Hz}$ at $4.18,4.20$, and 4.22 femtomole $\mathrm{Ca}_{\text {tot }}$, respectively. Note, the $\mathrm{Ca}^{2+}$ transient $\left(\left[\mathrm{Ca}^{2+}\right]_{\mathrm{blk}}\right)$ is plotted in $(\mathrm{C})$ instead of $\left[\mathrm{Ca}^{2+}{ }_{\text {tot }}\right]_{\mathrm{jnc}}$ in the bifurcation diagram. The $\left[\mathrm{Ca}^{2+}\right]_{\text {jnc }}$ is the key factor initiating the spontaneous $\mathrm{Ca}^{2+}$ release.

The connection between the limit cycle identified in the bifurcation analysis and the cycle of spontaneous $\left[\mathrm{Ca}^{2+}\right]$ fluctuations in the bulk cytosol space $\left(b l k ;\left[\mathrm{Ca}^{2+}\right]_{b l k}\right)$ was examined by conducting 
numerical time integration of the same minimal model (Figure 1C). Around the threshold Catot level for initiating the limit cycle in Figure 1A, the Catot was increased with a step size of 0.02 femtomole. The minimal model was quiescent up to 4.16 femtomole, and the cyclic $\left[\mathrm{Ca}^{2+}\right]_{\mathrm{blk}}$ transient was firstly observed at 4.18 femtomole. The frequencies of the $\mathrm{Ca}^{2+}$ transient increased with increasing $\mathrm{Ca}_{\text {tot }}$ as shown in Figure 1A. These responses of the minimal model were completely reversible when Catot decreased.

\subsection{Absence of Automaticity Inherent in Plasma Membrane Ionic Channels in the PVC}

The PVC model showed a resting potential $\left(\mathrm{V}_{\text {rest }}\right)$ at $-68 \mathrm{mV}$, which was similar to that observed in experiments $(>-75 \mathrm{mV})$. This less negative resting potential, compared to ventricular cells, is due to a much lower density of the inward rectifier potassium current $\left(I_{\mathrm{K} 1}\right)$ distribution compared with ventricular myocytes. Okamoto et al. revealed a hyperpolarization-activated $\mathrm{Cl}^{-}$current $\left(I_{\mathrm{Clh}}\right)$ at a voltage range more negative than the resting membrane potential $\left(\mathrm{V}_{\text {rest }}\right)$ [8]. This $I_{\mathrm{Clh}}$ potentially stabilizes the low $\mathrm{V}_{\text {rest }}$ by antagonizing any kind of hyperpolarizing current, such as the $I_{\mathrm{K} 1}$. $I_{\mathrm{Clh}}$ can provide the largest inward current during strong hyperpolarizing pulses, but at the $V_{\text {rest }}$ level, the magnitude of $I_{\mathrm{Clh}}$ activation is the lowest in the present mathematical model (violet trace in Figure 2D lower panel). Although $I_{\mathrm{Clh}}$ was not calculated in most of the simulations, $I_{\mathrm{Clh}}$ potentially depolarized the $\mathrm{V}_{\text {rest }}$ by $\sim 7 \mathrm{mV}$ in the PVC model, as suggested in experiments by Okamoto et al. [8].

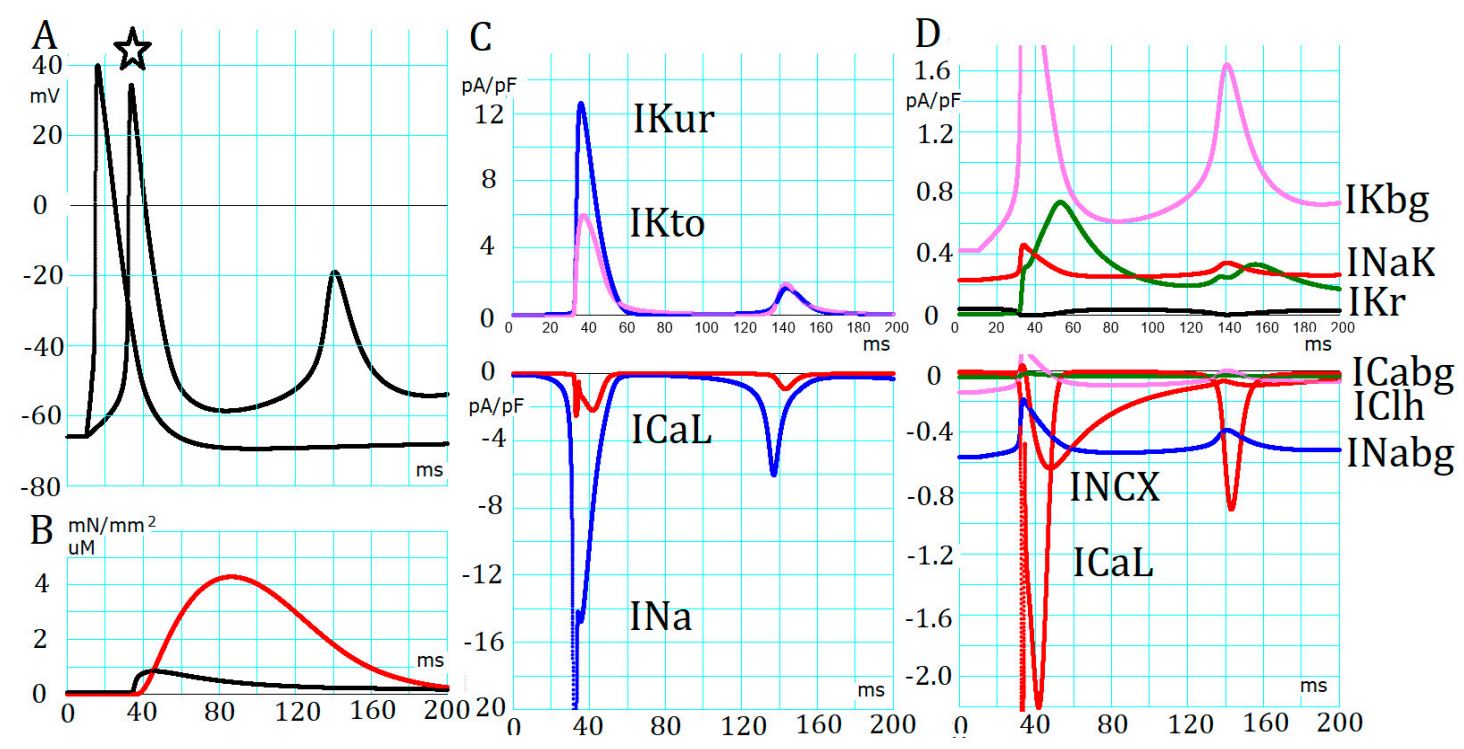

Figure 2. Membrane excitation in the absence of adrenergic (AR) stimulation: (A) Two records of action potential evoked by applying -5 ( $3 \mathrm{~ms}$ in duration) or $-0.5 \mathrm{pA} / \mathrm{pF}$ (180 ms) current pulses were superimposed. The star mark indicates an action potential (AP) evoked with a smaller pulse; (B) the $\mathrm{Ca}^{2+}$-transient (black, $\mu \mathrm{M}$ ) and the developed force of contraction (red, $\mathrm{mN} / \mathrm{mm}^{2}$ ); (C,D) membrane currents shown at a low gain and at a high gain, respectively. Outward and inward currents are shown in the upper and the lower panels, respectively. Resting potential $=-66.0 \mathrm{mV},\left[\mathrm{Na}^{+}\right]_{c y t}=5.7 \mathrm{mM}$, $\left[\mathrm{K}^{+}\right]_{c y t}=117 \mathrm{mM}$, and $\left[\mathrm{Ca}^{2+}\right]_{S R r l}=0.71 \mathrm{mM}$.

The membrane excitation was examined in a cell model after equilibration without application of electrical stimulation for $\sim 100 \mathrm{~s}$ (Figure 2). The two records of action potential superimposed in Figure $2 \mathrm{~A}$ were evoked by either a brief electrical stimulus $(-5 \mathrm{pA} / \mathrm{pF})$, or a longer and smaller pulse (190 ms in duration).

The AP duration was $\sim 30 \mathrm{~ms}$ at $-40 \mathrm{mV}$, which is in the same range of ventricular and atrial myocytes in rats $[7,8,27]$, but is clearly shorter than AP in the SA node pacemaker cells in rats [28]. The maximum rate of AP increased was mediated by the transient component of sodium current $\left(I_{\mathrm{Na}}\right)$ and was $\sim 98.6 \mathrm{~V} / \mathrm{s}$. Repolarization was mainly caused by the inactivation of $I_{\mathrm{Na}}$, and was facilitated by 
the simultaneous activation of $I_{\mathrm{Kto}}$ and $I_{\mathrm{Kur}}$ (Figure 2C). The role of $I_{\mathrm{CaL}}$ in maintaining the plateau potential of cardiac AP was largely compromised by the much larger transient outward potassium current $\left(I_{\text {Kto }}\right)$ and ultra-rapid outward potassium current $\left(I_{\text {Kur }}\right)$. $I_{\text {CaL }}$ triggered CICR from SR to evoke the peak amplitude of the $\mathrm{Ca}^{2+}$ transient of $\sim 1 \mu \mathrm{M}$ to induce the developed tension of the myofilaments (Figure 2B).

The record of membrane currents evoked by the long pulse are demonstrated in Figure 2C,D, which were used to examine membrane automaticity of the PVC. Depolarization to a less negative potential range than $-60 \mathrm{mV}$ evoked an $\mathrm{AP}$, followed by brief damping oscillations, but failed to evoke repetitive APs. The $\mathrm{V}_{\mathrm{m}}$ during the diastolic period is largely determined by the balance of major currents of outward-going $I_{\mathrm{NaK}}$, the background currents of $I_{\mathrm{Kbg}}$ and $I_{\mathrm{Kr}}$ (Figure 2D, upper panel), and the inward-going $I_{\text {Nabg }}$ and $I_{\mathrm{NCX}}$ (Figure 2D, lower panel). Even if larger depolarizing current pulses were applied, no repetitive APs were observed. We concluded that the inactivation of $I_{\mathrm{Na}}$ during the AP was not removed at the diastolic potential levels during the current pulse because the activation of $I_{\text {Kto }}$ and $I_{\text {Kur }}$ quickly ceased during the falling phase of the AP. The amplitude of $I_{\mathrm{Kr}}$ (depicted in green in Figure 2D) is smaller than the $I_{\mathrm{Kbg}}$. This is in strong contrast to the pacemaker mechanism of SA node cells [28], where the $I_{\mathrm{CaL}}$ is relieved from inactivation through hyperpolarization caused by the activation of $I_{\mathrm{Kr}}$ by the preceding AP. The amplitude of $I_{\mathrm{Kr}}$ assumed in the present model (depicted in green in Figure 2D) was too small to generate an appreciable size of a tail current on repolarization, in agreement with the experimental study [8]. We concluded that no stable cycle of APs arises in the membrane ionic system of the PVC model.

\subsection{Generation of $A P_{T D}$ and an Activation Threshold for $\mathrm{Ca}^{2+}{ }_{\text {tot }}$}

The bifurcation analysis (Figure 1) applied to the intracellular $\mathrm{Ca}^{2+}$ dynamics in the absence of membrane ion fluxes revealed that spontaneous and repetitive $\mathrm{Ca}^{2+}$ transients were initiated by increasing $\mathrm{Ca}_{\text {tot }}$ above a certain threshold level $\left(\mathrm{Ca}_{\text {tot,thr }}=4.18\right.$ femtomole $)$ in the absence of plasma membrane ion fluxes. In the simulation shown in Figure 3, the spontaneous activity was recorded in the presence of intact plasma membrane currents.

The intracellular $\mathrm{Ca}_{\text {tot }}$ was technically increased step by step by enlarging the scaling factor of $I_{\text {Cabg }}$. The spontaneous discharge of $\mathrm{AP}_{\mathrm{TD}}$ appeared when $\mathrm{Ca}_{\text {tot }}$ was increased above 3.878 femtomole in the absence of AR stimulation, whereas the threshold $\mathrm{Ca}_{\text {tot }}$ decreased to 3.617 femtomole in the presence of $0.15 \mu \mathrm{M}$ [ISO] and $0.15 \mu \mathrm{M}\left[\mathrm{IP}_{3}\right]$. Although the cycle length was markedly different, in both cases, the time course of $\mathrm{V}_{\mathrm{m}}$ was flat during diastole except for a small slow diastolic depolarization of a few $\mathrm{mV}$ observed over $\sim 300 \mathrm{~ms}$ after the preceding AP (Figure $3 \mathrm{~A}, \mathrm{C}$ ). The $\mathrm{Ca}^{2+}$ flux $\left(\mathrm{J}_{\mathrm{Ca}}\right)$ from SR via RyR (passive leak component ( $\mathrm{J}_{\text {leak_sR }}$ ) and active release component $\left(\mathrm{J}_{\text {rel__sR }}\right)$ ), and via $\mathrm{InsP}_{3} \mathrm{R}\left(\mathrm{J}_{\mathrm{InsP}} \mathrm{PR}\right)$ recovered in parallel with the replenishment of $\left[\mathrm{Ca}^{2+}\right]_{S R r l}$ within the following $400-500 \mathrm{~ms}$ because of the $\mathrm{Ca}^{2+}$ diffusion from SR uptake sites. The total continuous $\mathrm{Ca}^{2+}$ efflux $\left(\mathrm{J}_{\text {rel__SR }}\right)$ finally evoked the final full $\mathrm{Ca}^{2+}$ release as indicated by the rapid fall of $\left[\mathrm{Ca}^{2+}\right]_{S R r l}$ through an increase in $\left[\mathrm{Ca}^{2+}\right]_{j n c}$.

To confirm the involvement of TD in triggering APs, the amplitude of TD was depressed by increasing the membrane $I_{\mathrm{K} 1}$ conductance temporarily by six-fold (Figure $3 \mathrm{~B}$ ) or by three-fold (Figure 3D) approximately 1-3 s before the start of the recorded segment in the figure. This intervention blocked the AP generation and revealed the presence of TD in response to the spontaneous $\mathrm{Ca}^{2+}$ release. The amplitude of TD was $10-13 \mathrm{mV}$ and the $V_{m}$ at their peak was ca. $-61 \mathrm{mV}$, most probably more negative than the threshold potential of $I_{\mathrm{Na}}$ activation.

Note that the downward deflection of $\left[\mathrm{Ca}^{2+}\right]_{S R r l}$ showed double peaks: One synchronized with the start of $\mathrm{TD}$ and the other with the foot of the $\mathrm{AP}$ (or the activation of $I_{\mathrm{CaL}}$ ) every time when $\mathrm{AP} \mathrm{PD}_{\mathrm{TD}}$ was triggered, whereas the second peak disappeared when $\mathrm{TD}$ failed to trigger $\mathrm{AP} \mathrm{P}_{\mathrm{TD}}$.

The distribution of $\mathrm{Ca}_{\text {tot }}$ was 30\% in SR uptake site (SRup), $24 \%$ in SR releasing site (SRrl), and $43 \%$ in blk mostly bound with the buffer, and the minor components were found in $j n c(1.3 \%)$ and $i z(2.3 \%)$ in control and remained within $\pm 5 \%$ in various experimental conditions examined in the present study. 

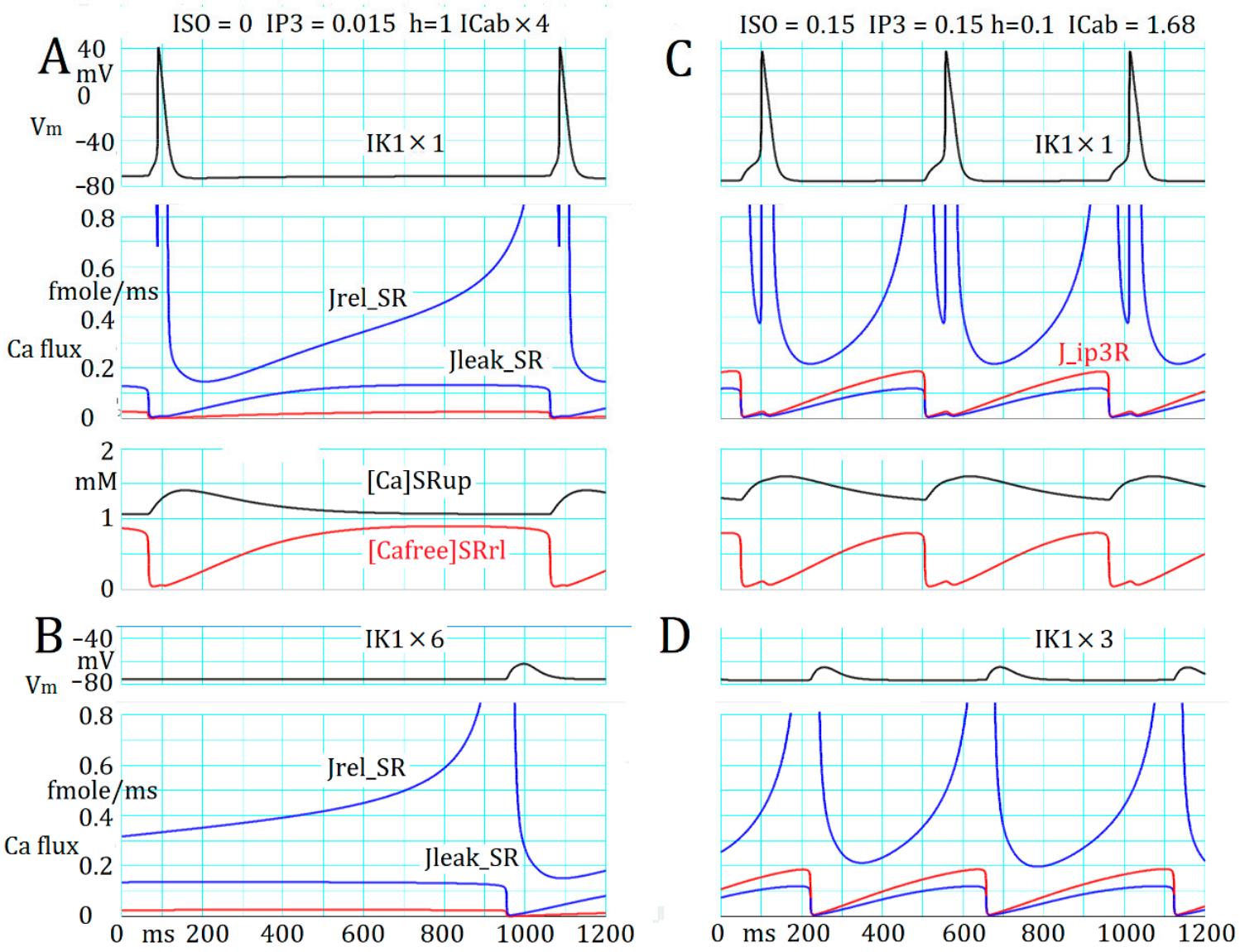

Figure 3. (A) Time-dependent changes in $\mathrm{J}_{\mathrm{RyR}}, \mathrm{J}_{\mathrm{IP} 3 \mathrm{R}}$ (blue and red in the middle panel), $\left[\mathrm{Ca}^{2+}\right]_{S R u p}$ and $\left[\mathrm{Ca}^{2+}\right]_{S R r l}$ (black and red in the bottom panel), when the repetitive action potential (AP; top panel) was evoked. (B) The transient depolarization (TD) when triggering APs was interfered with by increasing the inward rectifier potassium current $\left(I_{\mathrm{K} 1}\right)$ conductance six-fold. Almost the same time course of $\mathrm{J}_{\mathrm{RyR}}$, $\left[\mathrm{Ca}^{2+}\right]_{S R u p}$, and $\left[\mathrm{Ca}^{2+}\right]_{S R r l}$ were observed but are not demonstrated. (C,D) Records were obtained as in $A$ and $B$ in the presence of noradrenaline (NA) stimulation. The triggering AP by the preceding TD in (C) was much delayed if compared with records in (A). This is because the amplitude of TD was partially depressed through the enlargement of $I_{\mathrm{NaK}}$ through an accumulation of $\left[\mathrm{Na}^{+}\right]_{\mathrm{i}}$ during the repetitive $A P_{T D}$.

Alternatively, the $\mathrm{AP}_{\mathrm{TD}}$ s could be evoked by applying NA at $0.15 \mu \mathrm{M}$ at the control $s f I_{\mathrm{Cabg}}=1.68$. Figure $3 \mathrm{C}, \mathrm{D}$ show $\mathrm{AP}_{\mathrm{TD}}$ as in Figure $3 \mathrm{~A}, \mathrm{~B}$, and demonstrate that the interval between the two successive $\mathrm{AP}_{\mathrm{TD}} \mathrm{S}$ is much reduced (interval $=\sim 500 \mathrm{~ms}$ ), and the preceding TD evoked by the spontaneous $\mathrm{Ca}^{2+}$ release is obvious before the rising phase of the AP. Again, no slow diastolic depolarization was observed, and a rapid decay in $J_{\mathrm{Ca}}$ via a cluster of RyRs (couplon) clearly precedes the onset of TD, and the second notch of $J_{\mathrm{Ca}}$ was caused by the opening of LCC during the rising phase of the AP. The TD from the rising phase of the AP was isolated by increasing $s f I_{K 1}$ by three-fold (Figure 3D). The decrease in the TD amplitude in Figure 3D compared to that in Figure 3B was due to the enlarged $I_{\mathrm{NaK}}$ through the accumulation of $\left[\mathrm{Na}^{+}\right]$during the $\mathrm{AP}_{\mathrm{TD}}$ burst.

The threshold $\mathrm{Ca}_{\text {tot }}$ level for initiating the $\mathrm{AP}_{\mathrm{TD}}$ was examined in four combinations of two [ISO] of 0 and $0.2 \mu \mathrm{M}$, with two [ $\left.\mathrm{IP}_{3}\right]$ of 0.015 and $0.15 \mu \mathrm{M}$. The threshold $\mathrm{Ca}_{\text {tot }}$ at the $0.15 \mu \mathrm{M}\left[\mathrm{IP}_{3}\right]$ was higher (3.86 and 3.83 femtomole) than the value of (3.65 and 3.59 femtomole) obtained at $0.015 \mu \mathrm{M}$ $\left[\mathrm{IP}_{3}\right]$. For a reference level of $\mathrm{Ca}_{\mathrm{tot}}$, a representative 3.86 and 3.59 femtomole levels will be indicated in graphs of plotting time courses of $\mathrm{Ca}_{\text {tot }}$ in the following section. 


\subsection{Separation of $\alpha 1$ - and $\beta 1-A R$ Influences on $C a_{t o t}$ under Resting Condition}

The findings in both Figures 1 and 3 indicate that the increase in $\mathrm{Ca}_{\text {tot }}$ is the key factor for the initiation of the $\mathrm{AP}_{\mathrm{TD}}$ in the present $\mathrm{PVC}$ model. Therefore, activation of the individual target components LCC, SERCA, and the $\mathrm{Na}^{+} / \mathrm{K}^{+}$pump via $\beta 1$-AR stimulation were examined by modifying $\mathrm{Ca}_{\text {tot }}$ at a saturating concentration of ISO $(0.2 \mu \mathrm{M})$. In Figure $4 \mathrm{~A}$, the increase in Catot evoked by the full member activation of $\beta 1$-AR stimulation (LCC, SERCA, and $\mathrm{Na}^{+} / \mathrm{K}^{+}$pump) was compared with different combinations of target activation. The increase in $\mathrm{Ca}_{\text {tot }}$ evoked by activating LCC plus SERCA was slightly larger than the control response. The separated $\mathrm{Na}^{+} / \mathrm{K}^{+}$pump activation (the last trace in Figure 4) showed that the initial slight increase in $\mathrm{Ca}_{\text {tot }}$ was soon converted to a decrease during the ISO application due to a gradual decrease in $\mathrm{Ca}_{\text {tot }}$ through the NCX-mediated $\mathrm{Ca}^{2+}$ extrusion driven by the accelerated $\mathrm{Na}^{+} / \mathrm{K}^{+}$pump. The influence of LCC activation is synergistic with the SERCA activation because these two molecules work together in transporting $\mathrm{Ca}^{2+}$ from extracellular space to the SR space. Ca $\mathrm{a}_{\text {tot }}$ was markedly decreased by increasing the cytosolic $\left[\mathrm{IP}_{3}\right]$ (Figure 4B), which was applied to represent the activation of $\alpha 1$-AR. The application of two concentrations of $\mathrm{IP}_{3}$ caused a dose-dependent decrease in $\mathrm{Ca}_{\text {tot }}$ as shown by removing the desensitization of the receptor at $\left[\mathrm{IP}_{3}\right]$ of 0.075 , and $0.15 \mu \mathrm{M}$. If the desensitization (DS) was intact $(0.15 \mu \mathrm{M}+\mathrm{DS})$, the initial decreasing phase of $C a_{\text {tot }}$ was interrupted by the time-dependent desensitization.

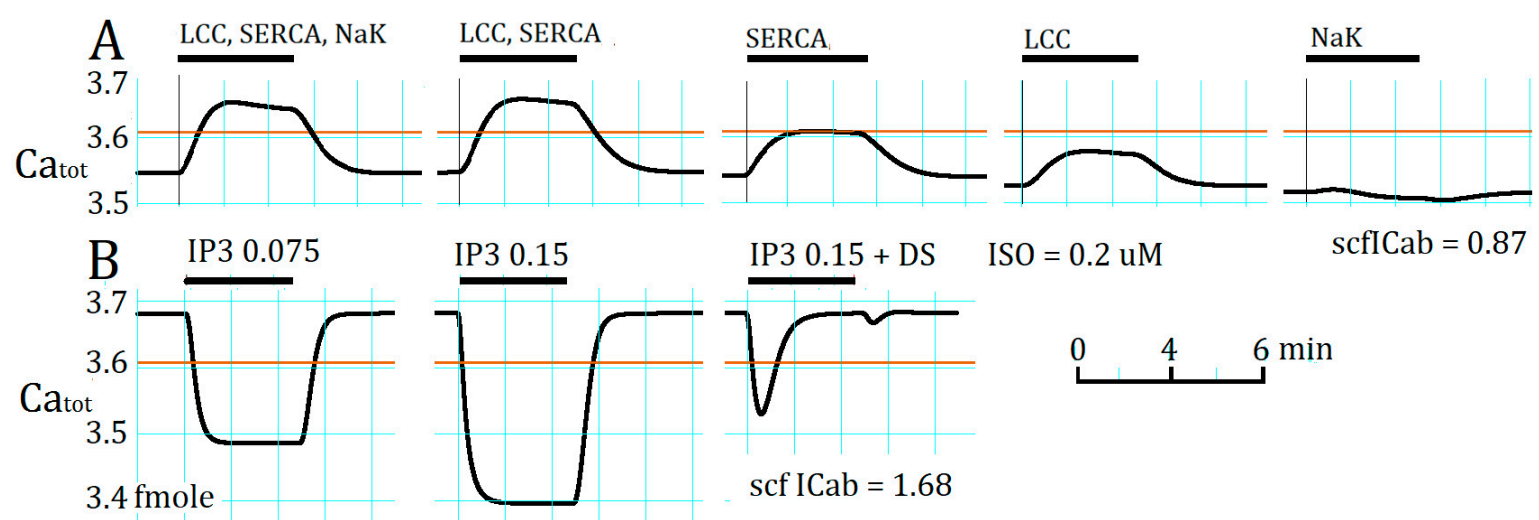

Figure 4. The influence of activating the individual components of NA-target molecules; (A) L-type $\mathrm{Ca}^{2+}$ channel (LCC), sarcoplasmic/endoplasmic reticulum calcium pump (SERCA), and $\mathrm{Na}^{+} / \mathrm{K}^{+}$of the $\beta 1-\mathrm{AR}$; (B) $\mathrm{InsP}_{3} \mathrm{R}$ of the $\alpha 1-\mathrm{AR}$. Catot (femtomole) was plotted against the simulation time (min). The horizontal bars above the record indicate the duration of modification of each factor. The desensitization of the $\alpha 1-\mathrm{AR}$ was removed to determine the maximum influence of their influence on $\mathrm{Ca}_{\text {tot }}$, except in the last application of $0.15 \mathrm{mM}\left[\mathrm{IP}_{3}\right]$. The desensitization of the $\beta 1-\mathrm{AR}$ was intact, but small in magnitude. The control level of $\mathrm{Ca}_{\text {tot }}$ was reduced in (A) by decreasing scf $_{\text {Cab }}$ to 0.87 to avoid a relatively large increase in $\mathrm{J}_{\mathrm{Ca} \_ \text {SR }}$ evoked by increasing $\mathrm{Ca}_{\text {tot }}$ near the activation threshold in the absence of $\beta 1-A R$ stimulation. The horizontal thin brown line indicates the threshold level of $\mathrm{Ca}_{\text {tot }}$ in the presence of NA stimulation.

\subsection{Marked Latency before the Onset of Repetitive $A P_{T D}$ Generation after AR Stimulation}

In both tissue [9] and isolated rat cell preparations [7], a train of spontaneous AP was evoked after an extraordinary long latency (several minutes) after the application of NA. A plausible mechanism was already demonstrated in Figure 4B. The transient decrease in $\mathrm{Ca}_{\text {tot }}$ induced by activating $\operatorname{InsP}_{3} \mathrm{R}$ ( $\alpha 1-\mathrm{AR}$ ) might counteract the $\beta 1$-AR activation, which promotes the $\mathrm{AP}_{\mathrm{TD}}$ burst by increasing $\mathrm{Ca}$ tot through $I_{\mathrm{CaL}}$ and SERCA activation (Figure $4 \mathrm{~A}$ ). This was the case, as shown in Figure 5(A2), where the $\mathrm{Ca}_{\text {tot }}$ rapidly decreased (by $\sim 7 \%$ ) after the start of AR stimulation. In this simulation, the control $\mathrm{Ca}_{\text {tot }}$ level was set slightly lower than the threshold of initiating $\mathrm{AP}_{\mathrm{TD}}$ (green vertical line) in the absence of AR stimulation. Factors involved in this response are shown in Figure 5(A4). The open probability ( $\mathrm{pO}_{\text {InsP3R }}$ ) of $\mathrm{InsP}_{3} \mathrm{R}$ (green) quickly increased from 0.00027 to a peak of 0.00385 and then decayed to 
0.00039 due to the desensitization of the $\alpha 1-\mathrm{AR}$ receptor activation. The $\mathrm{Ca}_{\text {tot }}$ followed a time course similar to $\mathrm{pO}_{\text {InsP3R }}$ (Figure 5(A2)). The slightly higher desensitized $\mathrm{pO}_{\text {InsP3R }}$ than the control was due to a rise in $\mathrm{Ca}_{\text {tot }}$. Note, the $\mathrm{InsP}_{3} \mathrm{R}$ can be partially activated by $\mathrm{Ca}^{2+}$. Figure 5(A3) indicates that the $\left[\mathrm{Ca}^{2+}\right]_{S R \text { up }}$ and $\left[\mathrm{Ca}^{2+}\right]_{S R r l}$, the major store site of $\mathrm{Ca}_{\mathrm{tot}}$, followed the similar time course as Catot.
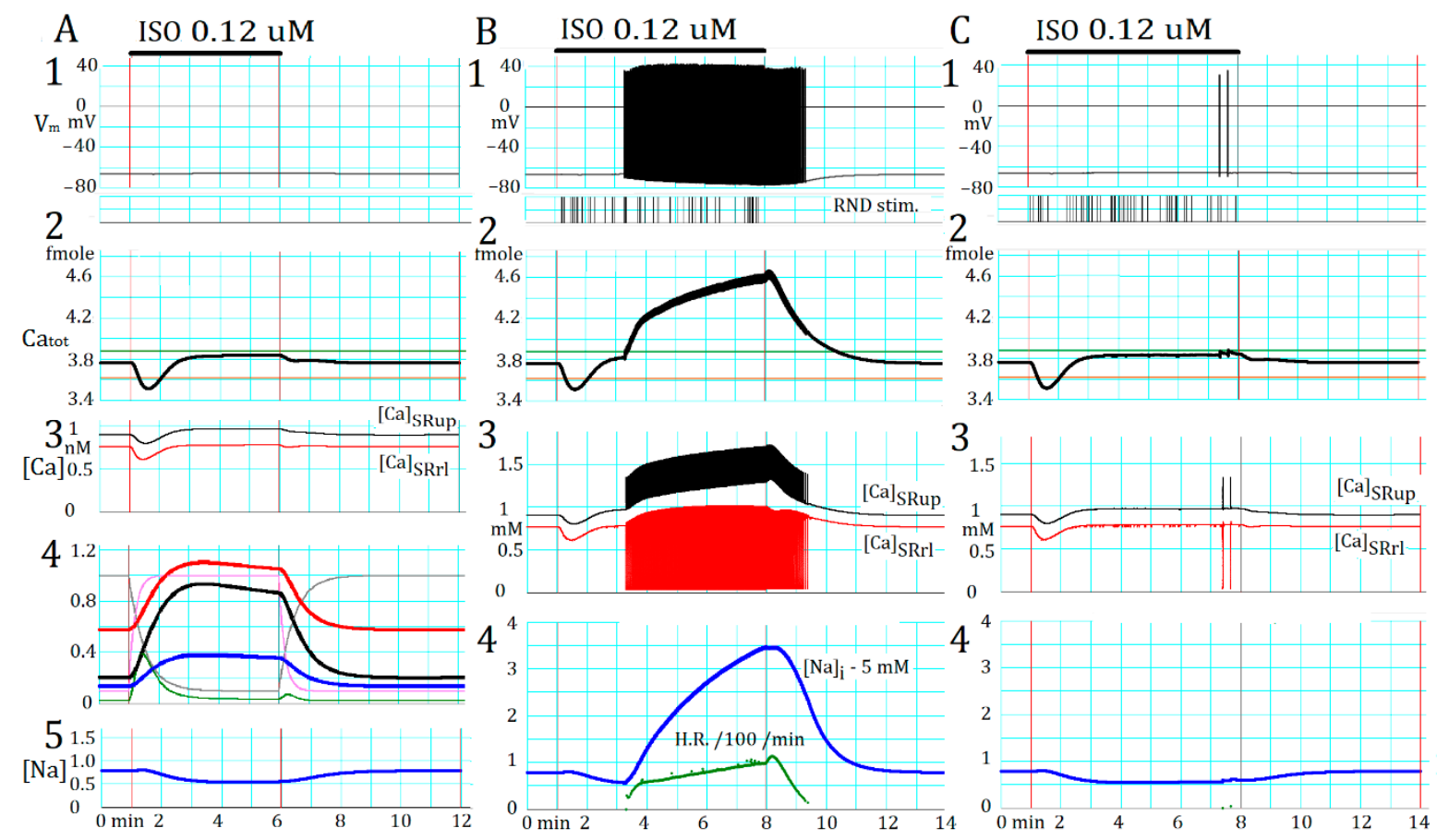

Figure 5. Initiation of a train of $\mathrm{AP}_{\mathrm{TD}}$ by the $\alpha 1$-adrenergic receptor (AR) stimulation. The application of $0.12 \mu \mathrm{M}$ ISO and $0.15 \mu \mathrm{M} \mathrm{IP} 3$ is indicated by the horizontal bars at the top of each column and the pair of vertical lines. (A) $\mathrm{AP}_{\mathrm{TD}}$ was not induced. $(\mathrm{B}, \mathrm{C})$ The random triggering signals applied are shown in the lower part of $\mathrm{B} 1$ and $\mathrm{C} 1$ (random (RND) stim) to induce $\mathrm{AP}_{\mathrm{TD}}$. The responses of $\mathrm{V}_{\mathrm{m}}(1)$, $\mathrm{Ca}_{\text {tot }}(2),\left[\mathrm{Ca}^{2+}\right]_{S R u p}$ and $\left[\mathrm{Ca}^{2+}\right]_{S R r l}(3)$, and $\left[\mathrm{Na}^{+}\right]_{\mathrm{i}}(5$ in $\mathbf{A}$ and 4 in $\mathbf{B}, \mathbf{C})$ are shown in each column. The time courses of $a f_{\mathrm{CaL}}\left(\times 0.5\right.$, red), $a f_{\mathrm{SERCA}}$ (black), $a f_{\mathrm{Na} / \mathrm{K}}$ (blue), and $\mathrm{pO}_{\text {InsP3R }}(\times 100$, green) shown in Figure 5(A4) are applicable to responses in $(\mathbf{B}, \mathbf{C})$. The rate of $\mathrm{AP}_{\mathrm{TD}}$ discharge $(/ \mathrm{min} / 100)$ appears only in Figure 5(B4). The horizontal green and brown lines are the threshold Catot measured in the absence and presence of AR stimulation, respectively.

The time courses of the $\beta 1-\mathrm{AR}$ stimulation of LCC ( $a f_{\mathrm{CaL}}$, red trace in Figure 5(A4)), SERCA ( $a f_{\text {SERCA }}$, black), and $\mathrm{Na}^{+} / \mathrm{K}^{+}$pump ( $a f_{\mathrm{NaK}}$, blue) are biphasic because of delayed fractional (30\%) desensitization of $\beta 1-\mathrm{AR}$. The discharge of $\mathrm{AP}_{\mathrm{TD}}$ evoked a full CICR, and thereby $\left[\mathrm{Ca}^{2+}\right]_{S R r l}$ decreased to a minimum level (Figure 5(B3)). The $\left[\mathrm{Ca}^{2+}\right]_{S R \text { up }}$ increased approximately parallel to the rise in $\left[\mathrm{Ca}^{2+}\right]_{b l k}$, and showed a transient increase due to the uptake of $\mathrm{Ca}^{2+}$ via SERCA at every $\mathrm{Ca}^{2+}$ transient. The wash out of the influence of AR stimulant took an exponential time course and lasted for $\sim 2 \mathrm{~min}$.

\subsection{Involvement of the Spontaneous Membrane Fluctuations in Determining the Latency}

In the control run shown in Figure 5A, the PVC remained quiescent because the Catot level was still lower than the reference level (green line) of the spontaneous $\mathrm{AP}_{\mathrm{TD}}$ discharge even after the desensitization of $\alpha 1-\mathrm{AR}$. The AP burst was initiated only when the $\mathrm{Ca}_{\text {tot }}$ was further increased by augmenting the $\beta 1-\mathrm{AR}$ stimulation. In such case, a train of $\mathrm{AP}_{\mathrm{TD}}$ s started at a given delay, different from the experimental finding of large variation in the 0-10 min latency [7]. For example, if scfI Cabg was increased from 1.68 to $2.2, \mathrm{Ca}$ tot was still lower than the reference level, but the application of a saturating concentration of ISO $(0.2 \mu \mathrm{M})$ evoked a train of $\mathrm{AP}_{\mathrm{TD}}$ after a latency of $181.94 \pm 0.5 \mathrm{~s}(\mathrm{mean} \pm \mathrm{SD}$, $n=13$ ). This is in strong contrast to the marked experimental variations in the latency. We suggest 
variable time courses of gradual accumulation of $\mathrm{Ca}_{\text {tot }}$ after the $\mathrm{AR}$ stimulation. In the simulation (Figure 5(A2)), however, the accumulation of $\mathrm{Ca}_{\text {tot }}$ reached a peak within two minutes. We examined an alternative possibility of the miniature $V_{m}$ fluctuations, most probably caused by sporadic CICR . The sporadic CICR was imitated using a random function (see Section 4) and the simulation results demonstrated in Figure 5B,C were obtained using the same protocol as in Figure 5A at the standard $s f I_{\text {Cabg }}=1.68\left(\mathrm{Ca}_{\text {tot }}=3.765\right.$ femtomole $)$. The frequency of sporadic CICR was approximately adjusted to the experimental records using a conventional RND function (see Section 4). The timing of random stimulation is shown by the vertical bars below the $V_{m}$ record. Figure $5 B, C$ provide typical examples of both success and failure of triggering repetitive $\mathrm{AP}_{\mathrm{TD}}$. The size of the sporadic $\mathrm{CICR}$ was variable at individual CICR events, as evidenced by the miniature fluctuations in $\left[\mathrm{Ca}^{2+}\right]_{S R r l}$ in the absence of continuous $\mathrm{AP}_{\mathrm{TD}}$ generation (Figure $5 \mathrm{C}$ ). Thus, the sporadic $\mathrm{CICR}$ mostly failed to evoke $\mathrm{TD}$ in visible amplitude to evoke $\mathrm{AP}_{\mathrm{TD}}$, and the $\mathrm{AP}_{\mathrm{TD}}$ was triggered randomly. In the case of Figure $5 \mathrm{C}$, two sporadic $\mathrm{AP}_{\mathrm{TDs}}$ were evoked toward to the end of the $\mathrm{AR}$ stimulation, but failed to start the repetitive $\mathrm{AP}_{\mathrm{TD}}$ s. In contrast, enough TD amplitude was evoked before the desensitization of $\beta 1$-AR to trigger the $\mathrm{AP}_{\mathrm{TD}}$ burst at a higher probability in Figure $5 \mathrm{~B}$.

The repetitive generation of $\mathrm{AP}_{\mathrm{TD}} \mathrm{S}$ was progressively accelerated as indicated by the plot of discharge frequency (Figure 5(B4), green curve). This is consistent with the bifurcation analysis results (Figure 1) that the frequency of the limit cycle of events increased with increasing $\mathrm{Ca}_{\text {tot }}$ in the $\mathrm{Ca}^{2+}$ dynamics when separated from the membrane function. In Figure $5 \mathrm{~B}$, the discharge of $\mathrm{AP}_{\mathrm{TD}}$ increased $\mathrm{Ca}_{\text {tot }}$ through the activation of membrane $I_{\mathrm{CaL}}$, and thereby positive feedback is involved in the rising phase of the spontaneous rate. This positive feedback was counteracted by the progressive increase of outward-going $I_{\mathrm{NaK}}$ through the accumulation of $\left[\mathrm{Na}^{+}\right]_{\mathrm{cyt}}$ (Figure 5(B4)), which was induced by the $\mathrm{Na}^{+} / \mathrm{Ca}^{2+}$ exchange via NCX. If the accumulation of $\left[\mathrm{Na}^{+}\right]_{\text {cyt }}$ was augmented by increasing the $\beta 1-\mathrm{AR}$ simulation, the increase in outward $I_{\mathrm{NaK}}$ current blocked triggering $\mathrm{AP}_{\mathrm{TD}}$ by decreasing the amplitude of $\mathrm{TD}$ (not shown). In this case, the repetitive $\mathrm{AP}_{\mathrm{TD}}$ generation was interrupted, but resumed when the accumulation of $\left[\mathrm{Na}^{+}\right]_{\mathrm{cyt}}$ was relieved by the extrusion of $\mathrm{Ca}^{2+}$ via NCX. Thus, the $\mathrm{AP}_{\mathrm{TD}}$ burst occurred intermittently (not shown). Note, $\left[\mathrm{Na}^{+}\right]_{\text {cyt }}$ was decreased via augmentation of the $\mathrm{Na}^{+} / \mathrm{K}^{+}$ pump by the $\beta 1-A R$ stimulation when the repetitive $\mathrm{AP}_{\mathrm{TD}}$ s were absent (Figure $5 \mathrm{~A}, \mathrm{C}$ ).

\subsection{Latency Histogram of the $A P_{T D}$ Burst}

The latency was measured by constructing a latency histogram from several data sets of 1000 trials of the AR stimulation, as shown in Figure 6, where each data set was obtained at the control $\mathrm{Ca}_{\text {tot }}$ $\left(s c f I_{\mathrm{Cab}}=1.68\right)$ but at different amplitudes of $I_{\mathrm{CaL}}$. In the control run $\left(I_{\mathrm{CaL}} \times 1.0\right.$, Figure $\left.6 \mathrm{~A}\right)$, the burst was successfully evoked in 996 trials, and the histogram showed a peak at bin No. 6 of 2.5-3.0 min. The success rate evoking a repetitive $\mathrm{AP}_{\mathrm{TD}}$ was sensitive to the amplitude of $I_{\mathrm{CaL}}$ (Figure $6 \mathrm{~B}-\mathrm{D}$ ), and the success rate drastically decreased to $33.4 \%$ by reducing the amplitude of $I_{\mathrm{CaL}}$ by $15 \%$ (Figure $6 \mathrm{D}$ ). This success rate is near to that (26.7\%) obtained in the experimental study [7]. The size of $\mathrm{Ca}^{2+}$ influx due to the activation of $I_{\mathrm{CaL}}$ and the uptake of $\mathrm{Ca}^{2+}$ into SR by SERCA play a key role in determining the time-dependent increase in $\mathrm{Ca}_{\text {tot }}$. Note, the $\left[\mathrm{Ca}^{2+}\right]_{n d}$ is largely dependent on $\left[\mathrm{Ca}^{2+}\right]_{S R r l}$ when a continuous $\mathrm{Ca}^{2+}$ leak is generated by both $\mathrm{InsP}_{3} \mathrm{Rs}$ and leak conductance of couplons. 

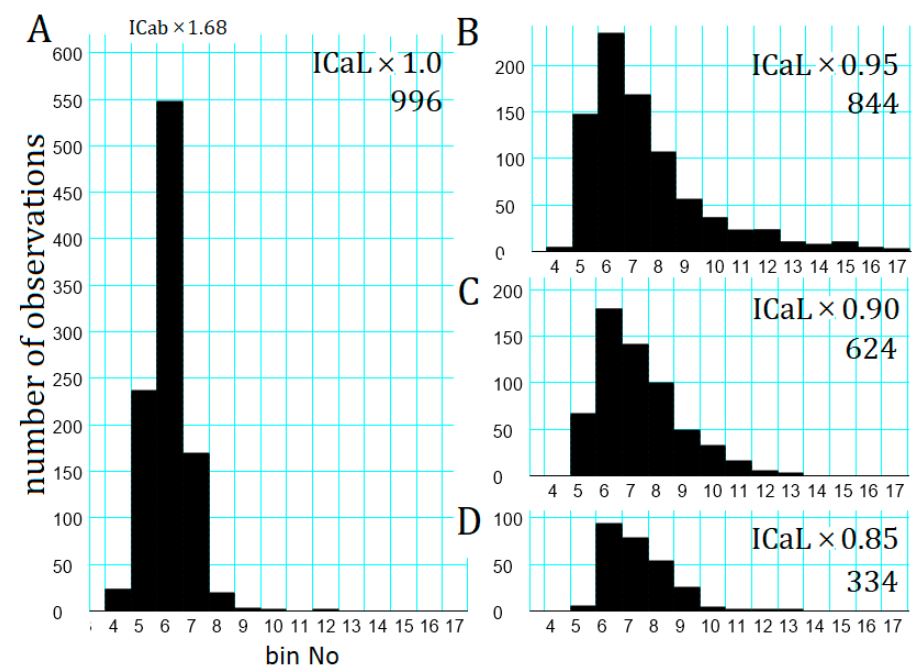

Figure 6. Latency histogram of the initiation of repetitive $\mathrm{AP}_{\mathrm{TD}}$ generation at different amplitudes of $I_{\mathrm{CaL}}$. The latency was measured from the onset of NA application to the time of the initial fifth $\mathrm{AP}_{\mathrm{TD}}$ discharge within a train. Vertical and horizontal axes for (B-D) are the same as in (A). The bin width was $30 \mathrm{~s}$. The amplitude of $I_{\mathrm{CaL}}$ in each series of simulation is indicated at up-right corner of (A-D) together with the number of successful triggerings of the repetitive generation of $\mathrm{AP}_{\mathrm{TD}} \mathrm{s}$ in 1000 trials.

\section{Discussion}

\subsection{Brief Summary}

The PVC model developed in the present study reconstructed well the electrical activity recorded in the PVCs dissociated from rat pulmonary veins by Okamoto et al. [7,8]. The model structure of CICR was refined in the human ventricular cell model [16], and was adopted in the presented PVC model including the $\mathrm{Ca}^{2+}$ spaces in the cytosol (Figure 7). The initiation of spontaneous APs in the model was attributed to the CICR (Figure 3), which was enhanced by the NA application, whereas the intrinsic membrane ionic mechanisms, described in cardiac pacemaker cells are not sufficiently developed to trigger spontaneous APs (Figure 2). After all membrane ionic fluxes were removed, the bifurcation analyses disclosed stable limit cycles over a certain range of $\mathrm{Ca}_{\text {tot }}$ within the cell (Figure 1). The threshold level for the initiation of the repetitive $\mathrm{AP}_{\mathrm{TD}}$ generation was slightly lower in the full model than in the model of cytosolic $\mathrm{Ca}^{2+}$ dynamics (Figure 5), most probably because the membrane components, such as NCX and LCC, which enhanced the positive feedback mechanisms of the spontaneous rhythm, are not involved in the minimal model. We demonstrated that the $\beta 1$-AR stimulation increased $\mathrm{Ca}_{\text {tot }}$, whereas the $\alpha 1$-AR activation temporary decreased $\mathrm{Ca}_{\text {tot }}$ (Figure 4). The marked latency of several minutes for the start of repetitive $\mathrm{AP}_{\mathrm{TD}}$ generation after the onset of stimulation could be explained by assuming the desensitization of $\alpha 1$-AR (Figure 5). Since the experimental findings on both the intracellular $\mathrm{Ca}^{2+}$ dynamics and signal transduction in rat PVC cells are still limited, the model proposed in this study may be revised in future studies. The presented simulation model, however, should provide a useful working hypothesis for conducting new experiments using dissociated cells. 


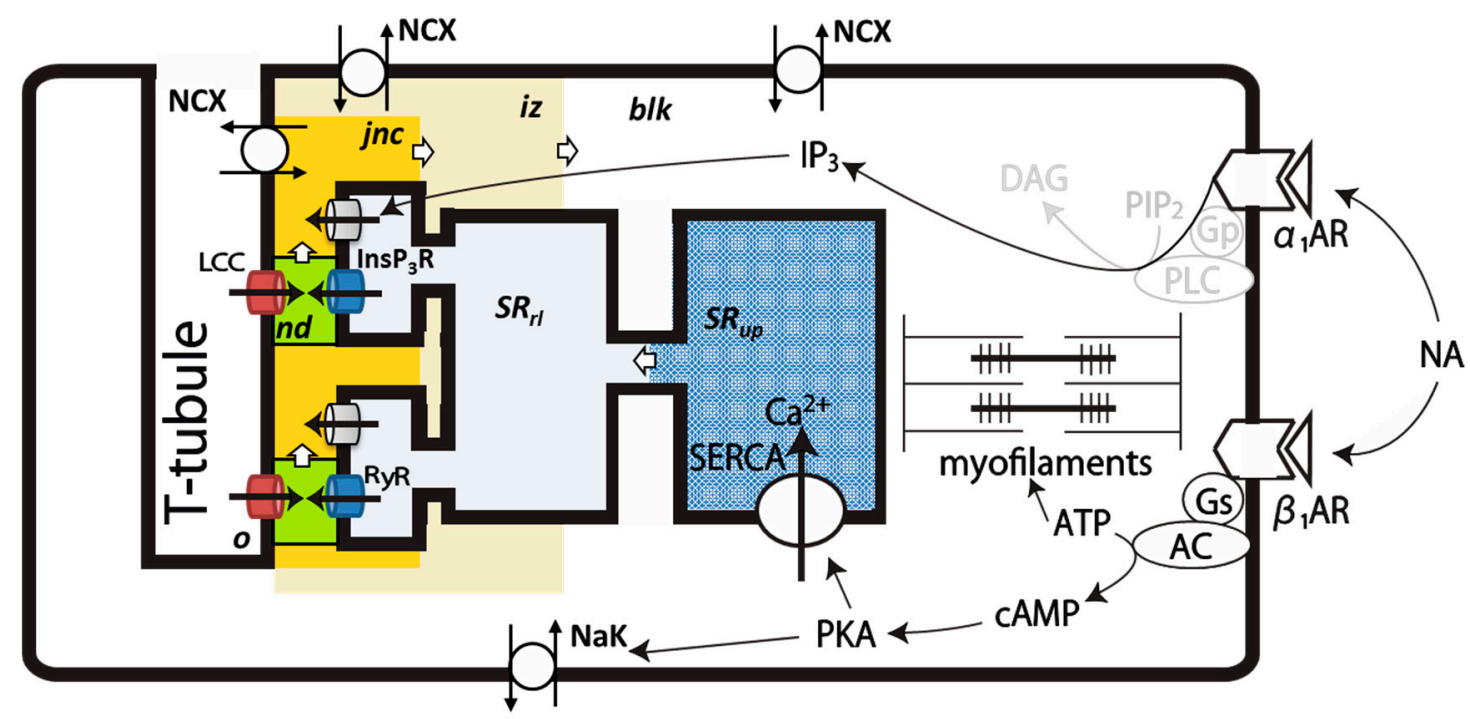

Figure 7. Signal transduction pathways for the $\alpha 1$ - and $\beta 1$-ARs, intracellular $\mathrm{Ca}^{2+}$ compartments, and distribution of $\mathrm{Ca}^{2+}$-transporting channels and transporters. Components in gray are not included in the model. Open arrows between compartments indicate the usual diffusion paths of $\mathrm{Ca}^{2+}$. The activation of type II ryanodine receptors (RyRs) and inactivation of LCC are determined by $\left[\mathrm{Ca}^{2+}\right]_{n d}$. The $\mathrm{Ca}^{2+}$ flux through $\mathrm{InsP}_{3} \mathrm{R}$ directs to $j n c$. If both LCC and RyRs are closed, $\left[\mathrm{Ca}^{2+}\right]_{n d}$ equals $\left[\mathrm{Ca}^{2+}\right]_{j n c}$.

\subsection{Co-Localization of Ins $P_{3} R$ with RyRs in the Sub-Sarcolemmal Space Supporting Spontaneous CICR}

The experimental studies in rat atrial myocytes demonstrated that a long lasting $\mathrm{Ca}^{2+}$ release from $\mathrm{SR}$ is induced by $\mathrm{IP}_{3}$, and through the co-localization of $\operatorname{Ins}_{3} \mathrm{R}$ with RyRs, the transient $\mathrm{Ca}^{2+}$ release is evoked [10]. Essentially the same mechanism was demonstrated when the $\operatorname{InsP}_{3} \mathrm{R}$ was activated by endothelin-1 (ET-1) [11]. The $\mathrm{Ca}^{2+}$ extrusion through NCX is augmented by this transient increase in $\left[\mathrm{Ca}^{2+}\right]$ and thereby a temporal transient membrane depolarization is evoked due to the electrogenic stoichiomety of $\mathrm{Na}^{+} / \mathrm{Ca}^{2+}$ exchange [19-22]. Mackenzie et al. directly recorded $\mathrm{Ca}^{2+}$ sparks as well as premature APs in the presence of ET-1 at a high probability of $75 \%$ in trials in rat atrial myocytes under $\alpha 1$-AR stimulation [11]. They demonstrated that a TD was evoked by an overlap of multiple $\mathrm{Ca}^{2+}$ sparks. The involvement of $\mathrm{Ins}_{3} \mathrm{R}$ was proven by recording larger amplitudes of premature AP when a membrane-permeable analogue of $\mathrm{IP}_{3}$ was applied in the extracellular medium [10]. The results of this simulation study using a new mathematical model of PVC in the present study agree with the basal $\mathrm{Ca}^{2+}$ mechanisms suggested by the previous studies. In the present study, a functional coupling of InsP $\mathrm{P}_{3} \mathrm{R}$ with RyRs was achieved by connecting the $\mathrm{Ca}^{2+}$ flux through $\mathrm{InsP}_{3} \mathrm{R}$ to the hypothetical $j n c$, which directly encircles multiple CaRUs based on nanodomain (nd), consists of LCC and the couplon. Note that in the absense of LCC activation at the resting membrane potential, the spontaneous activation of a couplon is only controlled by the $\left[\mathrm{Ca}^{2+}\right]$ within this $j n c$ in the Hinch formalism of CaRU [14-16].

\subsection{Peculiarity of $A P_{T D}$ Generated in $P V C$ S Compared to Aatrial and Ventricular Myocytes}

The spontaneous $\mathrm{TD}$ and the $\mathrm{AP}_{\mathrm{TD}}$ have been observed by activating the $\alpha 1$-AR more frequently in the atrial than in ventricular myocytes [10]. Atrial myocytes express $\operatorname{Ins}_{3} \mathrm{R}$ at a much higher density than in the ventricular myocytes. Ins $\mathrm{P}_{3} \mathrm{Rs}$ are co-localized with the couplons (RyRs) in the junctional SR, but are absent in the network SR (non-junctional SR) in the atrial myocytes. The T-tubules are densely distributed at each interval of the sarcomere pattern, and thereby the sum of the T-tubule membrane is almost comparable to the surface membrane in ventricular myocytes ( 78\%) [29]. Thus, the junctional $\mathrm{SR}$ is distributed throughout the depth of the myocytes. However, the ratio of $\mathrm{Ins}_{3} \mathrm{R}$-coupled couplons to non-coupled couplons should be much lower in the ventricular myocytes. Thus, the spontaneous CICR may occur at a much lower frequency in the ventricular myocytes. 
The PVCs show T-tubules and the $\operatorname{InsP}_{3} \mathrm{R}$ distributed along the sarcomere pattern as in the ventricular myocytes [7]. Thus, it is expected that the density of couplons co-localized with $\mathrm{InsP}_{3} \mathrm{R}$ should be much higher in PVCs than in atrial myocytes. This well agrees with PVs showing high frequencies of $\mathrm{AP}_{\mathrm{TD}} \mathrm{s}$ in both tissue preparations [2] as well as in dissociated cardiomyocytes [7], differently from the sporadic discharge of $\mathrm{AP}$ in the atrial myocytes during the activation of $\operatorname{Ins}_{3} \mathrm{R}[10,11]$. Note, the high frequency of $\mathrm{AP}_{\mathrm{TD}}$ generation is attributable to the frequency of the intracellular $\mathrm{Ca}^{2+}$ oscillations as indicated by the bifurcation analysis (Figure 1). The low resting membrane potential $(-70 \mathrm{mV})$ with low membrane conductance, most probably due to the low density of the $I_{\mathrm{K} 1}$ distribution, may further facilitate the discharge of repetitive $\mathrm{AP}_{\mathrm{TD}}$. In conclusion, The $\mathrm{AP}_{\mathrm{TD}}$ s may be evoked by essentially the same mechanism during AR stimulation as in the other working myocardial cells. The mechanisms may be highly enhanced in the PVCs to generate spontaneous repetitive $\mathrm{AP}_{\mathrm{TD}} \mathrm{s}$ in rat.

\section{4. $\mathrm{Ca}^{2+}$ Overload and $\beta 1-A R$ Stimulation Evoking Repetitive $A P_{T D}$ Generation in PVCS}

Okamoto et al. observed that spontaneous TDs or miniature potential fluctuations occurred at the resting potential even before the application of NA [7]. These potential fluctuations are barely observed in the working myocytes, such as atrial or ventricular myocytes, but was induced with a high success rate by depressing the $\mathrm{Na}^{+} / \mathrm{K}^{+}$pump by applying digitalis. This response is explained by the "Ca overload", which was expected to occur secondarily to the increase in $\left[\mathrm{Na}^{+}\right]_{i}[19,22]$. The $\mathrm{Ca}^{2+}$ overload is also caused by the repetitive stimulation of ventricular myocytes in the presence of $\alpha 1-\mathrm{NA}$ stimulation, and the spontaneous $\mathrm{Ca}^{2+}$-release from SR evokes the TD [30]. We introduced a hypothetical $I_{\text {Cabg }}$ for the purpose of varying the $\mathrm{Ca}_{\text {tot }}$ in PVCs. In the present study, the threshold of the $\mathrm{AP}_{\mathrm{TD}}$ discharge was determined by slowly increasing $\mathrm{Ca}_{\text {tot }}$ in a stepwise manner to allow for a quasi-steady state distribution of $\mathrm{Ca}^{2+}$ within the cell in each step change. The threshold $\mathrm{Ca}_{\text {tot }}$ levels of 3.88, 3.87, 3.66, and 3.61 femtomole were determined in the control, $\alpha 1-\mathrm{AR}, \beta 1-\mathrm{AR}$, and $\alpha 1$ - plus $\beta 1$-AR stimulation, respectively, after removing the desensitization of both receptors. This result is in good agreement with the finding in Figure 1 that the limit cycle of $\mathrm{Ca}^{2+}$ release was evoked simply by increasing the $\mathrm{Ca}_{\text {tot }}$ in the absence of the membrane ionic mechanisms.

\subsection{The Latency and Frequency of $A P_{T D}$ U Under NA Effects}

The simulation results in Figure 5 strongly suggest that the latency before the initiation of the $\mathrm{AP}_{\mathrm{TD}}$ generation might be determined by the desensitization of $\alpha 1$-AR in PVCs. In general, $\mathrm{G}_{\mathrm{q}}$-coupled receptors, such as $\alpha 1$-AR, ET-1 receptor, and angiotensin receptors, show desensitization after the binding of ligands [31-33]. The time course of desensitization has been demonstrated for the ET- 1 and angiotensin receptors [34,35]. Cooling et al. [17] successfully developed a mathematical model of the signal transduction evoked by the $\mathrm{G}_{\mathrm{q}}$-coupled receptors according to the experimental measurements. They suggested that the time course of desensitization is largely determined at the level of receptor molecules. However, they did not discuss the desensitization time course of $\alpha 1$-AR. We failed to find any experimental measurements of the $\alpha 1$-AR desensitization time course in cardiac myocytes. We only observed several references in which indirect findings were described without interpretation by the authors. Zhang et al. recorded the $I_{\mathrm{CaL}}$ response to phentolamine application in rat ventricular myocytes, and found that the $I_{\mathrm{CaL}}$ amplitude temporarily decreased over several minutes before the gradual increase in $I_{\mathrm{CaL}}$ [36]. They suggested that the decrease might be due to $\mathrm{Ca}^{2+}$-mediated inactivation induced by a temporal release of $\mathrm{SR} \mathrm{Ca}^{2+}$ through $\mathrm{InsP}_{3} \mathrm{R}$. Terzic et al. observed that the cell shortening evoked by the electrical stimulation of rat ventricular myocytes temporarily decreased in the same time course as $I_{\mathrm{CaL}}$ [37]. They suggested that this decrease in shortening might be due to the depletion of $\mathrm{Ca}^{2+}$ in SR. These findings strongly suggest the desensitization of $\alpha 1$-AR during phentolamine application. Although these responses were conducted at different ambient temperatures, the time courses were rather similar to the desensitization time course of $\alpha 1$-AR assumed in the present study. 
In general, the subthreshold TDs appeared randomly as described in atrial myocytes $[10,11]$. The variation in the latent period before the initiation of the $\mathrm{AP}_{\mathrm{TD}}$ generation is in agreement with the random occurrence of subthreshold TDs accompanied by transient elevations in intracellular $\mathrm{Ca}^{2+}[7]$. To simulate this sporadic triggering of $\mathrm{AP}_{\mathrm{TD}}$, the regularity of spontaneous generation of $\mathrm{AP}_{\mathrm{TD}}$ burst was avoided by lowering the $\mathrm{Ca}_{\text {tot }}$ to below the threshold level in the presence of $\beta 1$-AR activation. Then, the train of $\mathrm{AP}_{\mathrm{TD}}$ was triggered by the hypothetical random CICR. The experimental histogram obtained by Okamoto et al. [7] showed events of shorter latency than the time span of desensitization ( $\sim 1.5 \mathrm{~min}$ ). These shorter latency events might be simulated by increasing the conditioning $\mathrm{Ca}_{\text {tot }}$, or by decreasing the conductance of whole-cell $\mathrm{Ins}_{3} \mathrm{R}$. In experiments, these parameters might be largely variable between individual PVCs, so that the latency histogram showed a wider distribution in the experimental study than in the present simulation study, in which the histogram was obtained using one cell model with a set of initial values of the variables.

\subsection{Coupling Several Layers of Physiological Mechanisms to Regulate Ca tot in PVCs}

A regular time course of $\left[\mathrm{Ca}^{2+}\right]_{S R r l}$ change (core cycle) is evoked when the cell is stimulated by an isolated electrical stimulus; the CICR transiently depletes $\left[\mathrm{Ca}^{2+}\right]_{S R r l}$ at the terminal cysterna through excitation-contraction (EC) coupling. Then, the $\left[\mathrm{Ca}^{2+}\right]_{S R r l}$ gradually recovers through the $\mathrm{Ca}^{2+}$ diffusion from the $\mathrm{Ca}^{2+}$ uptake site of SR. If $\mathrm{Ca}^{2+}$ leaks through RyRs and $\operatorname{InsP}_{3} \mathrm{R}$ are added to this core cycle, any $\mathrm{Ca}^{2+}$ accumulation in $j n c$ potentially triggers the next event of $\mathrm{Ca}^{2+}$ release via CaRU. The bifurcation analysis (Figure 1) indicated that a stable limit cycle of this $\mathrm{Ca}^{2+}$ release is evoked by increasing the $\mathrm{Ca}_{\text {tot }}$ beyond a certain level in the absence of $\mathrm{Ca}^{2+}$ flux across the cell membrane.

If the membrane ionic fluxes are coupled with the core cycle of $\mathrm{Ca}^{2+}$ oscillation, positive and negative feedback mechanisms are added. As a negative feedback, the transient $\mathrm{Ca}^{2+}$ release via couplons primarily accelerates extrusion of $\mathrm{Ca}^{2+}$ to the extracellular space via NCX. If an enlarged $\mathrm{TD}$, evoked by the electrogenic $\mathrm{Na}^{+} / \mathrm{Ca}^{2+}$ exchange, triggers an $\mathrm{AP} \mathrm{TD}_{\mathrm{TD}}$, the extra $\mathrm{Ca}^{2+}$ influx through LCC activation can increase $\mathrm{Ca}_{\text {tot }}$, which may accelerate the core cycle of $\mathrm{Ca}^{2+}$ fluctuation and the spontaneous discharge of $\mathrm{AP}_{\mathrm{TD}}$ to start the positive feedback cycle to further augment the $\mathrm{Ca}_{\text {tot }}$.

The extrinsic regulation $\mathrm{Ca}_{\text {tot }}$ via $\beta 1-\mathrm{AR}$ and $\alpha 1-\mathrm{AR}$ activation may further potentiate finer but complicated tuning of the $\mathrm{Ca}^{2+}$ dynamics. Basically, the simultaneous activation of both LCC and SERCA efficiently accumulates $\mathrm{Ca}_{\text {tot }}$ through $\mathrm{Ca}^{2+}$ uptake into SR. The activation of $\mathrm{InsP}_{3} \mathrm{R}$ through $\alpha 1$-AR activation strongly decreases $\mathrm{Ca}_{\text {tot }}$ in combination with the $\mathrm{Ca}^{2+}$ extrusion by NCX. This simple antagonistic relationship between $\alpha 1$ - and $\beta 1$-ARs can be reversed to a synergistic relationship through the mechanism where by the frequency of the repetitive $\mathrm{AP} \mathrm{TD}_{\mathrm{TD}}$ generation is markedly increased by the faster recovery of $\left[\mathrm{Ca}^{2+}\right]_{S R r l}$ by facilitating positive feedback.

So far, the influences of AR stimulation revealed in the present study were mostly suggested under the maximized strength of both $\alpha 1$ - and $\beta 1$-AR stimulation. Therefore, the mechanisms revealed by such pathophysiological simulations might not be applicable to the homeostatic regulation of $\mathrm{Ca}_{\text {tot }}$ under physiological conditions, where a much finer neural regulation may be expected. For example, the neural activity of peripheral sympathetic fiber always changes dynamically by repeating short bursts of APs in synchrony with fluctuations in arterial pressure [38]. Under such moderate stimulation, a vast desensitization, as observed in Figure 5 or in real experiments during the continuous stimulation for $\sim 10 \mathrm{~min}$, might not be expected. Most probably, the $\alpha 1$-AR stimulation may simply stabilize the positive inotropic influence through the $\beta 1$-AR stimulation. The enhancement of $\mathrm{Na}^{+} / \mathrm{K}^{+}$pump via $\beta 1-\mathrm{AR}$ stimulation as well as the $\mathrm{InsP}_{3} \mathrm{R}$ activation via $\alpha 1-\mathrm{AR}$ should compromise the increase in $\mathrm{Ca}_{\text {tot }}$ through an enhancement of NCX. The conduction of the AP from the atrial tissue may induce stable positive inotropy of PVCs through the $\beta 1$-AR stimulation.

However, the simulation of the experimental findings successfully demonstrated cellular mechanisms in the present study. Thus, the mathematical model proposed is feasible for further examination of physiological mechanisms of the PVCs or might be applied to other cell types. 


\subsection{Limitations}

The functional mechanisms of individual components of the presented PVC model had not yet been clarified by conducting experiments in PVCs. To overcome this issue, the components of the model were developed based on the general reaction scheme, which has been established in a variety of cardiac cell types. This situation of limited experimental data is similar to that of developing human cardiac myocytes. However, mathematical models of human cardiac myocytes have been useful in providing new working hypotheses. The PVC model provided an assumption that the relatively long latency of several minutes should be proved by directly examining the desensitization of $\alpha 1$-AR. Variations in $\mathrm{Ca}_{\text {tot }}$ should be estimated or considered when the time course of NA effect is examined.

Experiments in both tissue and dissociated myocytes demonstrated that the $\mathrm{AP}_{\mathrm{TD}}$ burst was terminated with a long latency of many minutes after selectively blocking the $\alpha 1-\mathrm{AR}[2,7,9]$. However, our simulation study failed to reconstruct this finding because the $\alpha 1-\mathrm{AR}$ was already desensitized to the control level in the presented simulation before the application of the $\alpha 1$-AR blocker. To address this issue, the involvement of other factors should be considered, such as the activation of $I_{C a L}$ by the $\alpha 1-A R$ pathway and/or a decrease in membrane $\mathrm{K}^{+}$conductance, which takes a relatively long time course to develop. The nature of membrane $\mathrm{K}^{+}$conductance $\left(I_{\mathrm{Kbg}}\right)$ depressed through $\alpha 1-\mathrm{AR}$ stimulation has not yet been clarified. Alternatively, the desensitization of $\alpha 1-\mathrm{AR}$ might partially occur and some fraction remains intact. If so, the pharmacologic blockade of $\alpha 1-\mathrm{AR}$ might decrease the frequency of repetitive $\mathrm{AP}_{\mathrm{TD}}$ generation as indicated by the relationship between $\mathrm{InsP}_{3} \mathrm{R}$ conductance and the frequency (Figure 1); thereby, the positive feedback cycle between the increase in spontaneous frequency of $\mathrm{AP}_{\mathrm{TD}}$ through the accumulation of $\mathrm{Ca}_{\text {tot }}$ might be blocked, resulting in the cessation of spontaneous activity. We could simulate this mechanism under some narrow spectrum of the combination of modifying $\mathrm{Ca}_{\text {tot }}$, degree of desensitization, or the decrease in the membrane $\mathrm{K}^{+}$conductance. The complex mechanisms underlying the pluripotent nature of $\alpha 1-\mathrm{AR}$ stimulation remain to be clarified [36,37,39-46].

\section{Materials and Methods}

\subsection{Intracellular $\mathrm{Ca}^{2+}$ Compartments and Distribution of Ionic Channels and Transporters in the PVC Model}

Figure 7 shows a schematic representation of the model structure of a rat PVC. The T-tubule membrane provides the counterpart of the dyadic junction for the CICR. According to the Hinch model of the CaRU [14,15], individual CaRU is composed of one or a few number of LCC on the T-tubule membrane facing the couplons (clusters of RyRs) on the SR membrane. For activation and inactivation, both couplons and LCC refer to the same local $\mathrm{Ca}^{2+}$ concentration in the nanodomain (nd) cleft depicted in green. Each CaRU is separated from the others to support the local control of CICR, but a moderate cooperativity of multiple CaRUs is conserved by a local $\mathrm{Ca}^{2+}$ domain called jnc, which allows a temporal accumulation of released $\mathrm{Ca}^{2+}$ as firstly described in the HuVEC model [16,47]. $\mathrm{Ca}^{2+}$ accumulated in jnc gradually diffuses to $i z$ and then to $b l k$, in which myofilaments are located. Increased $\mathrm{Ca}^{2+}$ in each compartment is partly extruded by NCX. Note, only two representative CaRUs are demonstrated among many numbers of CaRUs in Figure 7. All CaRUs share a single common $\mathrm{Ca}^{2+}$ uptake site of the network SR spread in the $b l k$ for computational simplicity.

The major compartment of SR is $S R_{u p}$ equipped with SERCA, and provides its extension (terminal cysterna) to form $S R_{r l}$ as the other counterpart of the dyadic junction. The $S R_{r l}$ site contains the $\mathrm{Ca}^{2+}$ binding protein, calsequestrin, to increase the capacity of $\mathrm{Ca}^{2+}$ release. The $\mathrm{Ca}^{2+}$ released via InsP $\mathrm{P}_{3} \mathrm{R}$ diffuses into the jnc. The ion channels and transporters are exposed to different $\left[\mathrm{Ca}^{2+}\right]$ after the $\mathrm{Ca}^{2+}$ release, and their distribution to each compartment is given in the Supplemental Materials, but not shown in Figure 7. During the $\mathrm{Ca}^{2+}$ release, $\left[\mathrm{Ca}^{2+}\right]_{S R r l}$ is depleted to halt the $\mathrm{Ca}^{2+}$ release through the couplons.

NCX is distributed to $j n c, i z$, and $b l k$, and their activation evokes TD. If the peak of transient depolarization crosses the activation voltage threshold of $I_{\mathrm{Na}}, \mathrm{AP}_{\mathrm{TD}}$ is triggered. A series of $\mathrm{AP}$ discharge occurs when $\mathrm{Ca}_{\text {tot }}$ within the cell is increased above a threshold level. In the present study, 
the extent of $\mathrm{Ca}^{2+}$ overload was adjusted simply by magnifying the hypothetical $I_{\mathrm{Cabg}}$ assumed on the surface membrane. Simulating various mechanisms of the $\mathrm{Ca}^{2+}$ overload was beyond the scope of the present study. The myofilament contraction model of Negroni and Lascano (2008) was adopted to calculate the free $\mathrm{Ca}^{2+}$ concentration in the blk.

\subsection{Relationship Between Local $\left[\mathrm{Ca}^{2+}\right]_{n d}$ and Spontaneous $\mathrm{Ca}^{2+}$ Release}

In the Hinch model, the $\left[\mathrm{Ca}^{2+}\right]_{\text {nd }}$ is determined in different combinations of LCC and couplons under the assumption of instantaneous $\mathrm{Ca}^{2+}$ distribution [14,15].

$$
\left[\mathrm{Ca}^{2+}\right]_{n d}=\frac{\left[\mathrm{Ca}^{2+}\right]_{j n c}+f_{R} \times\left[\mathrm{Ca}^{2+}\right]_{S R r l}+f_{L} \times \frac{\delta V \cdot e^{-\delta V}}{1-e^{-\delta V}} \times\left[\mathrm{Ca}^{2+}\right]_{o}}{1+f_{R}+f_{L} \times \frac{\delta V}{1-e^{-\delta V}}}, \quad f_{R}=0.31, \quad f_{L}=0.014
$$

The opening of LCC or a couplon is approximately represented by the parameters $f_{R}$ and $f_{L}$ defined by Equations (2) and (3), respectively. $f_{L}$ and $f_{R}$ are zero when LCC and couplons are closed, respectively.

$$
\begin{aligned}
& f_{R}=\frac{G_{R}}{G_{d i f f}}, \\
& f_{L}=\frac{G_{L}}{G_{d i f f}},
\end{aligned}
$$

where $G_{L}$ and $G_{R}$ are $\mathrm{Ca}^{2+}$ conductivity through the LCC and couplons, respectively; and $G_{\text {diff }}$ represents the conductivity of $\mathrm{Ca}^{2+}$ diffusion across the hypothetical border between $n d$ and jnc. In the case of couplons, its activation is assumed to occur in an all or none manner; thus, $G_{R}$ represents the limiting conductance of the couplon, and $f_{R}$ provides the proportional coefficient in respect to $\left[\mathrm{Ca}^{2+}\right]_{S R r l}$. In the case of LCC, a single LCC is assumed so that the conductance $\mathrm{G}_{\mathrm{L}}$ represents the limiting conductance of LCC, but is an exponential function of the membrane potential $\mathrm{V}_{\mathrm{m}}$ as described by Equation (1). Note, $f_{L}$ and $f_{R}$ also provide proportional coefficients for $\left[\mathrm{Ca}^{2+}\right]_{n d}$ in respect to $\left[\mathrm{Ca}^{2+}\right]_{o}$ in the extra-cellular solution and $\left[\mathrm{Ca}^{2+}\right]_{S R r l}$, respectively.

An increase in $\left[\mathrm{Ca}^{2+}\right]_{n d}$ is the sole factor in determining the spontaneous $\mathrm{Ca}^{2+}$ release via couplon. Then, $\left[\mathrm{Ca}^{2+}\right]_{j n c}$ is calculated from the total amount of $\mathrm{Ca}^{2+}$ within the space $\left([\mathrm{Ca} \text { tot }]_{j n c}\right)$, which is determined by the four $\mathrm{Ca}^{2+}$ fluxes as represented by Equation (4).

$$
\frac{d\left[C a_{t o t}\right]_{j n c}}{d t}=-\frac{J_{C a, m}+J_{C a \_c o u p l o n}+J_{C a_{-} I n s P 3 R}-J_{C a_{-} j n c i z}}{V_{j n c}},
$$

where $V_{j n c}$ is the volume of $j n c$, and $J_{\mathrm{Ca}, \mathrm{m}}, J_{\mathrm{Ca}-\text {-couplon, }} J_{\mathrm{Ca}-\mathrm{InsP} 3 \mathrm{R}}$, and $J_{\mathrm{Ca} \text {,jnciz }}$ are membrane $\mathrm{Ca}^{2+}$ fluxes in the jnc space, $\mathrm{Ca}^{2+}$ release through couplon and $\mathrm{InsP}_{3} \mathrm{R}$, and $\mathrm{Ca}^{2+}$ diffusion between the $j n c$ and $i z$, respectively. Under a $\mathrm{Ca}^{2+}$-overload condition, the $\mathrm{J}_{\mathrm{Ca}-\text { rel }}$ through the basal openings of the couplon or activated $\mathrm{InsP}_{3} \mathrm{R}$ increases in proportion to the level of $\left[\mathrm{Ca}^{2+}\right]_{S R r l}$ above the threshold level. The amplitude of $\mathrm{Ca}^{2+}$ flux is determined by Equations (5) and (6).

$$
\begin{gathered}
J_{C a, R y R}=G_{R y R, b g} \cdot\left(\left[\mathrm{Ca}^{2+}\right]_{S R r l}-\left[\mathrm{Ca}^{2+}\right]_{j n c}\right), \\
J_{C a, I P 3 R}=G_{I P 3 R, b g} \cdot\left([\mathrm{Ca}]_{S R r l}-[\mathrm{Ca}]_{j n c}\right) .
\end{gathered}
$$

For Ca-buffers in $j n c, i z$, and $b l k$, see Supplemental Materials.

\subsection{Ion Channels and Transporters}

All ion channels and transporters included in the present PVC model are listed with references in the Abbreviations section. All the ion channels and transporters are distributed in each $\mathrm{Ca}^{2+}$ compartment (Table 1). 
Table 1. Distribution of plasma membrane channels and transporters.

\begin{tabular}{cccc}
\hline Channels and Transporters & $j n \boldsymbol{c}$ & $\boldsymbol{i z}$ & $\boldsymbol{b l k}$ \\
\hline $\mathrm{Ca}^{2+}$ insensitive channels & & & \\
$\left(I_{\mathrm{Na}}, I_{\mathrm{Kr}}, I_{\mathrm{K} 1}, I_{\mathrm{Kto}}, I_{\mathrm{Kur}}, I_{\mathrm{Clh}}, I_{\mathrm{Kbg}}\right.$, & - & 0.1 & 0.9 \\
$\left.I_{\mathrm{Nabg}}\right)$ & - & 0.1 & 0.9 \\
$I_{\mathrm{PMCA}}$ & - & 0.1 & 0.9 \\
$I_{\mathrm{NaK}}$ & 0.75 & 0.15 & 0.1 \\
$I_{\mathrm{CaL}(\mathrm{LCC})}$ & 0.03 & 0.25 & 0.72 \\
\hline$I_{\mathrm{NCX}}$ &
\end{tabular}

The $\mathrm{Cl}^{-}$channel having a large conductance was described during hyperpolarization in the rat PVC cells [8]. However, including $I_{\mathrm{Clh}}$ in the PVC model is difficult, since no experimental report on $\mathrm{Cl}^{-}$transporters is available for the PVC cell. To obtain $\mathrm{Cl}^{-}$homeostasis, we need to balance the passive $\mathrm{Cl}^{-}$flux with some $\mathrm{Cl}^{-}$transporters. At present, the PVC model does not include $I_{\mathrm{Clh}}$. In preliminary simulations, $I_{\mathrm{Clh}}$ was included only to estimate its contribution to the membrane potential. We found that the contribution of $I_{\mathrm{Clh}}$ to the membrane potential is relatively small at $\mathrm{V}_{\mathrm{m}}$ less negative than $-70 \mathrm{mV}$.

The equations of these ion currents and the transporters are given in Supplemental Materials. Only several currents with immediate significance for the spontaneous $\mathrm{APD}_{\mathrm{TD}}$ are described below.

In rat PVC cells, the amplitude of $I_{\mathrm{Na}}$ was larger when compared with $I_{\mathrm{Na}}$ in the atrial tissue, and the activation range was shifted to left in the current-voltage (I-V) relationship [6,48]. No obvious difference was reported in the density and kinetics between PVC and LA [3]. Okamoto et al. demonstrated that the inactivation of $I_{\mathrm{CaL}}$ is faster in the rat PVC cells compared to ventricular cells [7]. In the CaRU of the HuVEC model, the locus of $\mathrm{Ca}^{2+}$-mediated inactivation of LCC is $n d$ and the inactivation rate $\left(\mathrm{k}_{\mathrm{oc}}\right)$ is described as:

$$
k_{o c}=\frac{\left[C a^{2+}\right]_{x}}{K_{L}} \cdot \frac{f V_{m, a c t}}{T_{L}} \quad K_{L}=0.0044 m M, \quad T_{L}=147.51,
$$

where $f V_{m, a c t}$ is a parameter for the $V_{\mathrm{m}}$-dependent activation parameter and is used to describe the dependence of LCC inactivation on the opening of the voltage gate, and $K_{L}$ is used to represent the $\left[\mathrm{Ca}^{2+}\right]$-dependence in $n d$ or other $\left[\mathrm{Ca}^{2+}\right]$. We assumed that $75 \%$ of $I_{\mathrm{CaL}}$ was connected to $j n c$, and $15 \%$ to $i z$, and the rest to $b l k$. A slightly smaller $K_{L}\left(K_{L}=0.00154 \mathrm{mM}\right)$ was used for the at PVC cell model to increase the $\mathrm{Ca}^{2+}$ sensitivity.

Virtually no obvious amplitude of $I_{\mathrm{Kr}}$ tail current has been recorded on the jump from the positive potential to the holding potential in the voltage clamp experiment in rat PVCs [7]. However, in rat atrial cells [49,50], ventricular cells [50], and canine PVCs [3], the existence of $I_{\mathrm{Kr}}$ was revealed at a relatively small density. We included a minimum size of $I_{\mathrm{Kr}}$ in the PVC model to provide a repolarization reserve for technical reasons to avoid instability of $V_{m}$, which was observed around -20 to $40 \mathrm{mV}$ after the inactivation of both $I_{\mathrm{Kto}}$ and $I_{\mathrm{Kur}}$. Activation of a transient outward current was observed at the onset of the depolarizing pulse in the rat ventricular myocyte model by Pandit et al. [51]. The $I_{\text {Kur }}$ model was adopted from the mouse ventricular myocyte model by Bondarenko et al. [52].

The $I_{\mathrm{Clh}}$, found by Okamoto et al., showed slow voltage-dependent activation on hyperpolarization with a time course similar to that of the hyperpolarization-activated non-selective cation current in the SA node cell [8]. Thus, we applied the kinetic equation of $I_{\mathrm{h}}$ simplified by reducing the number of states to $C_{1}, C_{2}$, and $O$ states after optimizing the rate constants. The $I_{K 1}$ in PVCs seems much smaller in amplitude compared to the ventricular cells to allow the relatively low resting potential in PVC cells [7].

The histochemical examination of the NCX by Okamoto et al. [7] disclosed the localization of NCX near the T-tubules. This finding was represented by the $28 \%$ distribution of NCX near the T-tubule ( $2 \%$ in $j n c$ and $25 \%$ in $i z$ ) and the rest in $b l k$, respectively (Table 1 ). 


\subsection{Simulation of NA Stimulation of PVCs}

The mathematical model of the $\beta 1$-AR stimulation developed by Saucerman et al. [18] was adopted after minor modification $[53,54]$. The reaction cascade that generates cytosolic cyclic AMP (cAMP) and the activation of PKA evoked by $\beta 1-A R$ agonist ISO is described in the Supplemental Materials.

Doisne et al. never observed spontaneous activity in isolated pulmonary veins of rat under basal physiological conditions, but observed that the application of norepinephrine induced automatic electric activity [9], in agreement with the contractile activity observed by Maupoil et al. [2]. Okamoto et al. observed the spontaneous repetitive AP generation when $\alpha 1$ - and $\beta 1$-ARs were stimulated in dissociated PVCs, and also recorded major ionic current components of the PVCs [7]. In reconstructing the experimental data of Okamoto et al. [7,8], we selected SERCA, LCC, and the $\mathrm{Na}^{+} / \mathrm{K}^{+}$pump as key targets of the $\beta 1$-adrenergic regulation, and $\operatorname{Ins}_{3} \mathrm{R}$ and a kind of background $\mathrm{K}^{+}$conductance for the $\alpha 1$-AR regulation. Although RyRs are also the target of the $\beta 1$-adrenergic regulation, we did not calculate the modification of RyRs for simplicity, partly because the activation of the couplon occurred in an all-or-none manner during the CICR. Here, the "catecholamine effect" denotes the sum of these effects. The influence of individual affecters were examined by varying the activity of the corresponding target molecule.

\subsubsection{Implementation of $\beta 1-A R$ Effects}

We assumed two populations of the target molecules for each of $\mathrm{Na}^{+} / \mathrm{K}^{+}$pump, SERCA, and LCC; one is the phosphorylated fraction $\left(F r_{P K A}\right)$ by the catalytic subunit of PKA and the other is the dephosphorylated fraction by several kinds of phosphatase (PPs). In a normalized scheme, the reaction of phosphorylation is described by Equation (8):

$$
\left(1-F r_{P K A}\right) \underset{\beta}{\stackrel{\alpha}{\rightleftarrows}} F r_{P K A} .
$$

The time course of $F r_{P K A}$ after the onset of $\beta 1$-AR stimulation was calculated using Equation (9).

$$
\frac{d F r_{P K A}}{d t}=\alpha \cdot\left(1-F r_{P K A}\right)-\beta \cdot F r_{P K A}
$$

where a common time constant $(\tau)$ of phosphorylation was assumed for the three kinds of target protein. Since the activation time course takes several tens of seconds after the application of $\beta 1-A R$ stimulant, a $\tau$ of $40 \mathrm{~s}$ was assumed for convenience. The forward rate $\alpha$ in Equation (8) is dependent on the concentration of catalytic subunit of PKA (cat), a forward rate constant $k_{c a t}=0.0625 / \mathrm{mM} / \mathrm{ms}$ was determined by model adjustment, and the backward rate constant $\beta$ was obtained by Equations (10) and (11).

$$
\begin{gathered}
\alpha=k_{\text {cat }} \cdot c a t, \\
\beta=\frac{1}{\tau}-\alpha .
\end{gathered}
$$

When a basal phosphorylation (base) of target protein caused by kinases other than PKA is assumed, the sum of phosphorylated active fraction $\left(a f_{(\mathrm{t})}\right)$ of a target protein is given as a sum of two components denoted as base and delta.

$$
a f(t)=\text { base }+ \text { delta } \cdot F r_{P K A(t)} .
$$

The proportion of base/(base + delta) for $\mathrm{Na}^{+} / \mathrm{K}^{+}$pump, SERCA, and LCC were model adjusted to $25 \%, 10 \%$, and $43.5 \%$, respectively. 


\subsection{2. $\mathrm{Na}^{+} / \mathrm{K}^{+}$Pump}

The $\mathrm{Na}^{+} / \mathrm{K}^{+}$pump model used in the human ventricular cell (HuVEC) model [55] was adopted, since it was developed by referring to a wide variety of electrophysiological findings to apply the detailed thermodynamic framework of the original $\mathrm{Na}^{+} / \mathrm{K}^{+}$pump model [56]. The $\beta 1$-adrenergic regulation of the $\mathrm{Na}^{+} / \mathrm{K}^{+}$pump model was introduced by implementing the involvement of phospholemman (PLM) as described by Despa et al. [57]. According to their study, the activation of $\mathrm{Na}^{+} / \mathrm{K}^{+}$pump by the phosphorylation of PLM was represented by a decrease to $75 \%$ the control in the apparent $\mathrm{Na}^{+}$-dissociation constant $\left(K d_{, N a i}\right)$ of the cytosolic binding site. The decrease was calculated by applying a scaling factor $s f$ to the original $K_{d}$ in the four state model of $\mathrm{Na}^{+} / \mathrm{K}^{+}$pump.

$$
\overline{K d}_{N a i}=s f_{N a K} \cdot K d_{N a i} .
$$

To satisfy the thermodynamic constraint of:

$$
\frac{k_{1}^{+} k_{2}^{+} k_{3}^{+} k_{4}^{+} K_{d, K_{i}}^{2} K_{d . N a_{e}}^{3}}{k_{1}^{-} k_{2}^{-} k_{3}^{-} k_{4}^{-} K_{d, M g A T P} K_{d, K_{e}}^{2} K_{d . N a_{i}}^{3}}=K_{\sim M g A T P} \cdot e^{F V_{m} / R T},
$$

where the $K d_{, K e}$ for the extracellular binding site was increased by $s f^{-3 / 2}$ to obtain the increase in the $\mathrm{I}_{\mathrm{NaK}}[55,57]$, a $s f_{\mathrm{NaK}}=0.72$ was set for the $\mathrm{Na}^{+} / \mathrm{K}^{+}$pump relieved from the inhibitory action of PLM.

We assumed two populations of the $\mathrm{Na}^{+} / \mathrm{K}^{+}$pump, with phosphorylated PLM fractions (activated fraction, af) and non-phosphorylated fraction $(1-a f)$. The whole cell $I_{\mathrm{NaK}}$ was determined as a sum of control $I_{\mathrm{NaK}}$ and activated $\bar{I}_{\mathrm{NaK}}$,

$$
I_{\mathrm{NaK}}=(1-a f) \cdot I_{\mathrm{NaK}}+a f \cdot \bar{I}_{\mathrm{NaK}} \cdot
$$

\subsubsection{SERCA}

The biophysical model of SERCA that we developed by modifying the Tran et al. model [58] was used after adding the $\beta 1$-adrenergic regulation. SERCA belongs to the same family of the P-type ion pump as the $\mathrm{Na}^{+} / \mathrm{K}^{+}$ATPase; namely, the activity of SERCA was inhibited by the non-phosphorylated phospholamban (PLB), and SERCA was relieved from this inhibition through phosphorylation of PLB during the $\beta 1-A R$ stimulation. The regulation by AR was defined by decreasing the apparent $K_{d}$ for the cytosolic $\mathrm{Ca}^{2+}$ to half the control $\left(s f_{\mathrm{SERCA}}=0.5\right)$ when the PLB was phosphorylated. The thermodynamic constraint was satisfied by applying the same $s f$ to the rate $k_{-1}$, which was used as an adjustable parameter in the original model. The time course of activation was defined by Equation (12) and the amplitude of the $\mathrm{Ca}^{2+}$ flux into SR was calculated by Equation (17). The same time constant $\tau$ $=1 \mathrm{~s}$ was used for the $\beta 1-\mathrm{AR}$ regulation of $\mathrm{Na}^{+} / \mathrm{K}^{+}$.

$$
\overline{K d}_{C a i}=s f_{S E R C A} \cdot K d_{C q i} .
$$

The whole cell $J_{S E R C A}$ was determined as a sum of control $J_{S E R C A_{-} c}$ and activated $J_{S E R C A \_} \cdot$

$$
\mathrm{J}_{\text {SERCA }}=(1-a f) \cdot \mathrm{J}_{\text {SERCA } \_c}+a f \cdot \mathrm{J}_{\text {SERCA } \_} a \cdot
$$

\subsubsection{LCC}

The amplitude of $I_{\mathrm{CaL}}$ increased during the $\beta 1$-AR stimulation without a marked change in its time course. Thus, the amplitude of $I_{\mathrm{CaL}}$ is magnified when noradrenaline is applied to the model cell. We assumed that the fraction of non-phosphorylated population of LCC is $56.5 \%$ and shows virtually zero conductance in the absence of $\beta$-adrenergic stimulation. Thus, the whole cell conductance of $I_{\mathrm{CaL}}$ is proportional to $a f_{(\mathrm{t})}$ (Equation (12)). 


\subsection{5. $\alpha 1$-Adrenergic Signal, $\left[\mathrm{IP}_{3}\right]$}

We failed to find an $\alpha 1$-AR model to incorporate in the PVC model. In this study, the timedependent activation and desensitization of the receptor was simply represented by changes in the active second messenger $\left[\mathrm{IP}_{3 \mathrm{a}}\right]$ using a concentration $\left[\mathrm{IP}_{3}\right]_{(\mathrm{t})}$, and an inactivation $(i)$ parameter of the $\alpha 1$-AR at time $t$. To obtain $\left[\mathrm{IP}_{3}\right]$, equal to the control $0.015 \mathrm{mM}$ after the desensitization, a lower limit of 0.1 was applied to the range of $i_{\infty}$ :

$$
\begin{gathered}
{\left[I P_{3 a}\right]=i_{(t)} \cdot\left[I P_{3}\right]_{(t)},} \\
i_{(t+d t)}=i_{\infty}-\left(i_{\infty}-i_{(t)}\right) \cdot \exp \left(-\frac{d t}{\tau_{i}}\right) \quad \tau_{i}=30000\left(\mathrm{~ms}^{-1}\right), 0.1 \leq i_{\infty}<1 .
\end{gathered}
$$

The $\left[\mathrm{IP}_{3}\right]_{(\mathrm{t})}$ at time $t$ is also given by an exponential function:

$$
\left[I P_{3}\right]_{(t+d t)}=\left[I P_{3}\right]_{\max }-\left(\left[I P_{3}\right]_{\max }-\left[I P_{3}\right]_{(t)}\right) \cdot \exp \left(-\frac{d t}{\tau_{i p 3}}\right) \quad \tau_{i p 3}=5000\left(m s^{-1}\right) .
$$

\subsection{6. $\mathrm{InsP}_{3} \mathrm{R}$}

In the cardiac myocytes, the type II homologous isomer is the major component of $\operatorname{Ins}_{3} \mathrm{R}$ [59] and is expressed on the SR membrane near the T-tubules [7]. Thus, in the model, the $\operatorname{InsP}_{3} \mathrm{R}$ was exposed to jnc, so that its $\mathrm{Ca}^{2+}$ release plays a critical role in determining the bias level for the CICR. The open probability $\mathrm{pO}_{\mathrm{InsP}}$ R was calculated using the $\mathrm{InsP}_{3} \mathrm{R}$-II model [60]. The influence of $\mathrm{Ca}^{2+}$ on the $\mathrm{PO}_{\text {InsP3R }}$ was much less than that of $\mathrm{IP}_{3}$ over the range of $\left[\mathrm{Ca}^{2+}\right]$ during the $\mathrm{Ca}^{2+}$ transient. The resting level of $\left[\mathrm{IP}_{3}\right]$ was set to $0.015 \mu \mathrm{M}$ according to Cooling et al. [17] so that $J_{\text {InsP3R }}$ was virtually zero. The $\left[\mathrm{IP}_{3}\right]$ was increased 10 -fold $(0.15 \mu \mathrm{M})$ during the stimulation of $\alpha 1-\mathrm{AR}$. The $\mathrm{Ca}^{2+}$ flux via $\mathrm{InsP}_{3} \mathrm{R}$ channel was calculated using Equation (21).

$$
J_{\text {InsP3R }}=P_{I P 3 R} \cdot p O_{\text {InsP3R }} \cdot\left(\left[\mathrm{Ca}^{2+}\right]_{S R r l}-\left[\mathrm{Ca}^{2+}\right]_{j n c}\right) .
$$

\subsubsection{Background $\mathrm{K}^{+}$Current, $I_{\mathrm{Kbg}}$}

Doisne et al. observed a slow continuous depolarization of $\sim 21 \mathrm{mV}$ during a $15 \mathrm{~min}$ application of NA to the rat PV tissue, which was larger than the $+12 \mathrm{mV}$ depolarization in the atrial tissue [9]. Similar depolarization was observed in response to phenylephrine (a selective agonist for $\alpha 1$-AR) in the rat atrial tissue preparation by Jahnel et al. [61]. In our simulation, the AR-mediated decrease of the background $I_{\mathrm{Kbg}}$ was set at $20 \%-30 \%$ with a time constant of $120 \mathrm{~s}$ to obtain the experimental time course of depolarization.

$$
\begin{gathered}
I_{K_{b g}}=s f_{K_{b g}} \cdot G_{K_{b g}} \cdot\left(V_{m}-E_{K}\right) \\
s f_{K_{b g}(t+d t)}=s f_{K_{b g}(t)}+\left(s f_{K_{b g} \infty}-s f_{K_{b g}(t)}\right) \cdot \frac{d t}{\tau_{K b}} \quad \tau_{K b}=80000\left(m s^{-1}\right) .
\end{gathered}
$$

\subsection{Simulation of the Random Events of CICR}

If $\left[\mathrm{Ca}^{2+}\right]_{j n c}$ fluctuates over a range slightly lower than the threshold of full CICR activation, the membrane potential may vary randomly. However, in the conventional numerical integration of $\mathrm{d}\left[\mathrm{Ca}^{2+}\right] / \mathrm{dt}$, the average time course of $\left[\mathrm{Ca}^{2+}\right]_{j n c}$ only changes smoothly and continuously. In simulation, the random activation of a couplon could be technically evoked by introducing a random function in the present Hinch format of CICR. For practical purposes, the magnitude of $\left[\mathrm{Ca}^{2+}\right]_{j n c}$ was multiplied two-fold at a probability of 0.0007 when the random function implemented in the VB system provided a value larger than $(1-0.0007)$ at every step of numerical integration. This additional fluctuation randomly induced a full-blown CICR shown in Figure 5. Note, this modified $\left[\mathrm{Ca}^{2+}\right]_{j n c}$ is only used to determine the opening rate of a couplon, but does not interfere with the mass conservation of $\mathrm{Ca}^{2+}$ dynamics. 


\subsection{Changes in Membrane Potential and Ion Concentrations}

$A C_{m}$ of $115.3 \mathrm{pF}$ was assumed in the PVC model according to the measurements of Okamoto et al. [7]. The AP was triggered by applying a current pulse of $-5 \mathrm{pA} / \mathrm{pF}$ for $3 \mathrm{~ms}$. Changes in $\mathrm{V}_{\mathrm{m}}$ as well as the intracellular ion concentrations were calculated.

$$
\begin{aligned}
& I_{C a, t o t \_j n c}=I_{C a, C a L_{-} j n c}+I_{C a, N C X} j n c, \\
& I_{C a, t o t \_i z}=I_{C a, C a L_{\_} i z}+I_{C a, b b_{\_} i z}+I_{C a, N C X \_i z}+I_{C a, P M C A \_i z}, \\
& I_{C a, t o t \_b l k}=I_{C a, C a L \_b l k}+I_{C a, b b_{-} b l k}+I_{C a, N C X \_b l k}+I_{C a, P M C A \_b l k},
\end{aligned}
$$

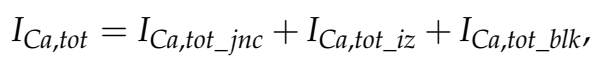

$$
\begin{aligned}
& I_{\mathrm{Na}, \text { tot }}=I_{\mathrm{Na}}+I_{\mathrm{Na} \text {,CaL_jnc }}+I_{\mathrm{Na}, \mathrm{CaL} \_ \text {iz }}+I_{\mathrm{Na}, \mathrm{CaL} \_ \text {blk }}+I_{\mathrm{Na}, \mathrm{bg}} \\
& +I_{\mathrm{Na}, \mathrm{NaK}}+I_{\mathrm{Na}, \mathrm{NCX} \_ \text {jnc }}+I_{\mathrm{Na}, \mathrm{NCX} \_\mathrm{iz}}+I_{\mathrm{Na}, \mathrm{NCX} \_ \text {blk }} \\
& I_{\mathrm{K}, \text { tot }}=I_{\mathrm{k}, \mathrm{K} 1}+I_{\mathrm{K}, \mathrm{Kr}}+I_{\mathrm{K}, \mathrm{Kto}}+I_{\mathrm{K}, \mathrm{ur}}+I_{\mathrm{K}, \mathrm{bg}}+I_{\mathrm{K}, \mathrm{Na}} \\
& +I_{\mathrm{K}, \mathrm{CaL} \_ \text {inc }}+I_{\mathrm{K}, \mathrm{CaL} \_ \text {iz }}+I_{\mathrm{K}, \mathrm{CaL} \_ \text {blk }}+I_{\mathrm{K}, \mathrm{NaK}}
\end{aligned}
$$

The concentration changes of intracellular ions were calculated by the numerical integration of the membrane fluxes across the surface membrane as well as the SR membrane.

$$
\begin{aligned}
& \frac{d C a_{t o t \_j n c}}{d t}=\left(-\frac{I_{C a, t o t \_j n c} \cdot C_{m}}{2 \cdot F}+J_{C a \_r e l}-J_{C a_{-} j n c i z}+J_{I P 3}\right) / V_{v o l \_j n c}, \\
& \frac{d C a_{t o t \_} i z}{d t}=\left(-\frac{I_{C a, t o t \_i z} \cdot C_{m}}{2 \cdot F}+J_{C a \_j n c i z}-J_{C a \_i z b l k}\right) / V_{v o l \_i z} \\
& \frac{d C a_{t o t \_b l k}}{d t}=\left(-\frac{I_{C a, t o t \_b l k} \cdot C_{m}}{2 \cdot F}-J_{C a \_S E R C A}+J_{C a \_i z b l k}\right) / V_{v o l \_b l k}, \\
& \frac{d C a_{S R u p}}{d t}=\frac{J_{C a \_S E R C A}-J_{C a \_t r a n s S R}}{V_{\text {vol_SRup }}}, \\
& \frac{d C a_{t o t \_S R r l}}{d t}=\frac{J_{C a \_t r a n s S R}-J_{C a \_r e l}-J_{I P 3}}{V_{v o l \_S R r l}}, \\
& \frac{d N a}{d t}=\frac{I_{N a, t o t} \cdot C_{m}}{F \cdot V_{\text {vol_cyt }}}, \\
& \frac{d K}{d t}=\frac{\left(I_{K, t o t}+I_{a p l}\right) \cdot C_{m}}{F \cdot V_{v o l \_c y t}}, \\
& \frac{d V_{m}}{d t}=-\left(I_{C a, t o t}+I_{N a, t o t}+I_{K, t o t}+I_{a p l}\right) .
\end{aligned}
$$

4.7. Bifurcation Analysis on the Ca ${ }^{2+}$ Dynamics Within the Cell in the Absence of Membrane Ionic Fluxes

The model equations were all translated into an ordinary differential equation (ODE) file. Initial values were obtained using a numerical simulation program. Then equilibrium points were calculated using xppaut [62]. When Hopf bifurcation points were obtained, limit cycles were calculated using a conventional computational tool "Auto" to plot a bifurcation diagram. Catot (attomole) was composed of various compartments as described by Equation (38).

$$
C a_{t o t}=\left[C a_{t o t}\right]_{j n c} \cdot V_{o l}^{j n c}+\left[C a_{t o t}\right]_{i z} \cdot V l_{i z}+\left[C a_{t o t}\right]_{b l k} \cdot V o l_{b l k}+\left[C a_{t o t}\right]_{S R r l} \cdot V o l_{S R r l}+\left[C a^{2+}\right]_{S R u p} \cdot V o l_{u p} \text { (attomole). }
$$

In the bifurcation diagram and the main text, the unit of $\mathrm{Ca}_{\text {tot }}$ is converted to femtomole from attomole. 
Supplementary Materials: Supplementary materials can be found at http://www.mdpi.com/1422-0067/20/12/ 2913/s1. Reference [63] appear in the Supplementary Materials

Author Contributions: Data curation, S.U., X.T., A.N. and Y.H.; Formal analysis, K.O. and A.A.; Investigation, Y.O. and A.N.; Methodology, S.U., K.O. and A.N.; Project administration, A.N. and A.A.; Software, S.U. and A.A.; Supervision, K.O., A.N., A.A. and Y.H.; Validation, X.T., Y.O. and Y.H.; Writing-original draft, S.U. and A.N.; Writing-review \& editing, Y.H.

Funding: This research was funded by JSPS KAKENHI (Grant-in-Aid for Young Scientists (B)) Grant Number JP16K18996 to Y.H.

Conflicts of Interest: The authors declare no conflict of interest.

\section{Abbreviations}

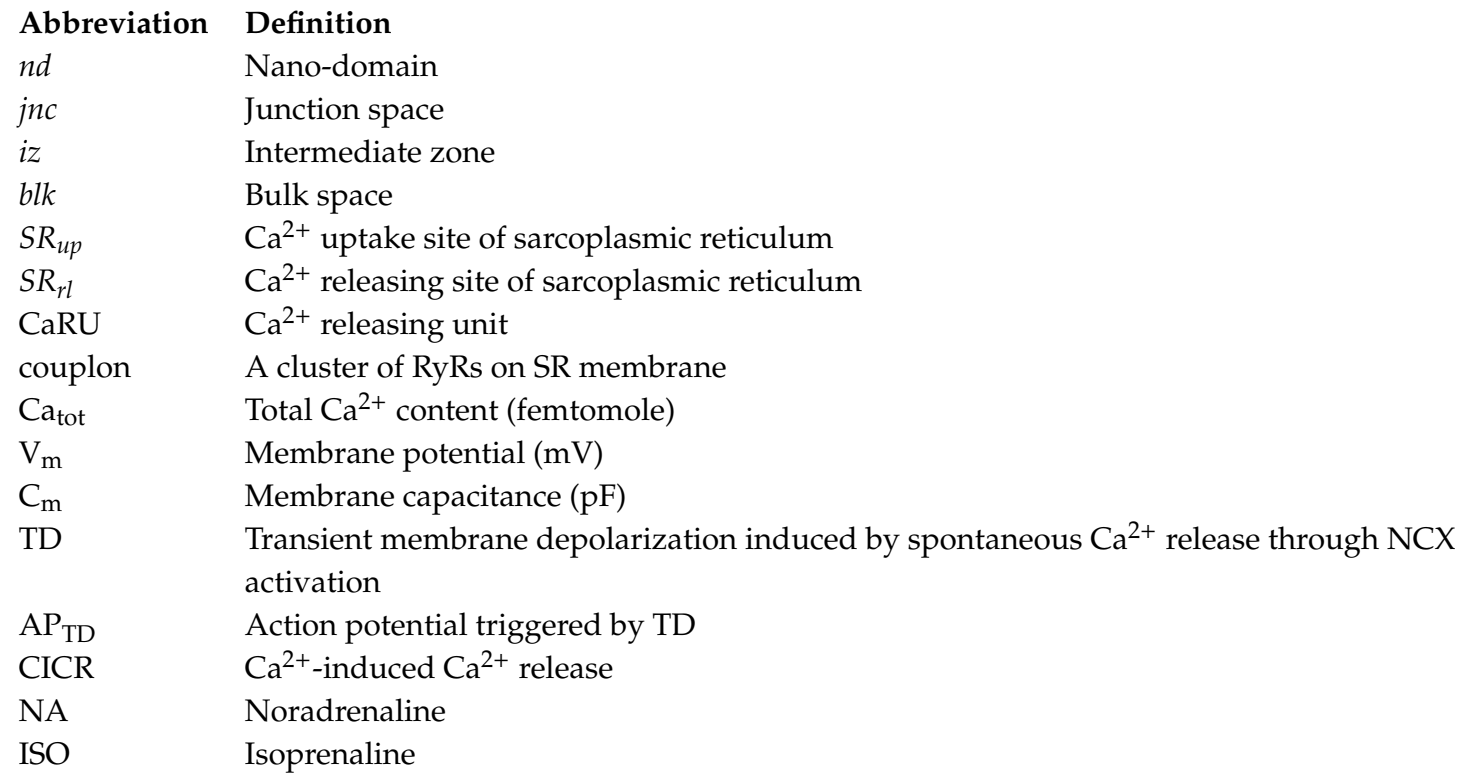

Ion channels and transporters in our PVC model

$\begin{array}{lll}\text { Abbreviation } & \text { Definition } & \text { Reference } \\ I_{\mathrm{Na}} & \text { Transient component of sodium current } & \text { HuVEC model [16] } \\ I_{\mathrm{CaL}(\mathrm{LCC})} & \text { L-type calcium current } & \text { HuVEC model [16] } \\ I_{\mathrm{Kr}} & \text { Delayed rectifier potassium current, fast component } & \text { HuVEC model [47] } \\ I_{\mathrm{K} 1} & \text { Inward rectifier potassium current } & \text { HuVEC model [16] } \\ I_{\mathrm{Kto}} & \text { Transient outward potassium current } & \text { Pandit et al. [51] } \\ I_{\mathrm{Kur}} & \text { Ultra-rapid outward potassium current } & \text { Bondarenko et al. [52] } \\ I_{\mathrm{Clh}} & \text { Hyperpolarization activated chloride current } & \text { Experimental data by Okamoto et al. [8] } \\ I_{\mathrm{Cab}}, I_{\mathrm{Nab}}, I_{\mathrm{Kb}} & \mathrm{Background} \text { currents for } \mathrm{Ca}^{2+}, \mathrm{Na}^{+} \text {and } \mathrm{K}^{+} & \text {Pandit et al. [51] } \\ I_{\mathrm{NCX}} & \mathrm{Na}^{+} / \mathrm{Ca}^{2+} \text { exchange current } & \text { HuVEC model [16] } \\ I_{\mathrm{NaK}} & \mathrm{Na}^{+} / \mathrm{K}^{+} \text {pump current } & \text { HuVEC model [16] } \\ \mathrm{SERCA} & \text { Sarcoplasmic/endoplasmic reticulum calcium pump } & \text { HuVEC model [16] } \\ \mathrm{InsP}_{3} \mathrm{R} & \text { Inositol (1,4,5)-trisphosphate receptor } & \text { Sneyd et al. [60] } \\ \mathrm{RyR} & \mathrm{Ryanodine} \mathrm{receptor} & \text { HuVEC model [16] }\end{array}$

\section{References}

1. Haissaguerre, M.; Jais, P.; Shah, D.C.; Takahashi, A.; Hocini, M.; Quiniou, G.; Garrigue, S.; Le Mouroux, A.; Le Metayer, P.; Clementy, J. Spontaneous initiation of atrial fibrillation by ectopic beats originating in the pulmonary veins. N. Engl. J. Med. 1998, 339, 659-666. [CrossRef] [PubMed]

2. Maupoil, V.; Bronquard, C.; Freslon, J.L.; Cosnay, P.; Findlay, I. Ectopic activity in the rat pulmonary vein can arise from simultaneous activation of $\alpha$-and $\beta 1$-adrenoceptors. Br. J. Pharm. 2007, 150, 899-905. [CrossRef] [PubMed] 
3. Ehrlich, J.R.; Cha, T.J.; Zhang, L.; Chartier, D.; Melnyk, P.; Hohnloser, S.H.; Nattel, S. Cellular electrophysiology of canine pulmonary vein cardiomyocytes: Action potential and ionic current properties. J. Physiol. 2003, 551, 801-813. [CrossRef] [PubMed]

4. Namekata, I.; Tsuneoka, Y.; Tanaka, H. Electrophysiological and pharmacological properties of the pulmonary vein myocardium. Biol. Pharm. Bull. 2013, 36, 2-7. [CrossRef] [PubMed]

5. Takahara, A.; Hagiwara, M.; Namekata, I.; Tanaka, H. Pulmonary Vein Myocardium as a Possible Pharmacological Target for the Treatment of Atrial Fibrillation. J. Pharm. Sci. 2014, 126, 1-7. [CrossRef]

6. Malecot, C.O.; Bredeloux, P.; Findlay, I.; Maupoil, V. A TTX-sensitive resting $\mathrm{Na}^{+}$permeability contributes to the catecholaminergic automatic activity in rat pulmonary vein. J. Cardiovasc. Electrophysiol. 2015, 26, 311-319. [CrossRef] [PubMed]

7. Okamoto, Y.; Takano, M.; Ohba, T.; Ono, K. Arrhythmogenic coupling between the $\mathrm{Na}^{+}-\mathrm{Ca}^{2+}$ exchanger and inositol 1,4,5-triphosphate receptor in rat pulmonary vein cardiomyocytes. J. Mol. Cell Cardiol. 2012, 52, 988-997. [CrossRef]

8. Okamoto, Y.; Kawamura, K.; Nakamura, Y.; Ono, K. Pathological impact of hyperpolarization-activated chloride current peculiar to rat pulmonary vein cardiomyocytes. J. Mol. Cell. Cardiol. 2014, 66, 53-62. [CrossRef]

9. Doisne, N.; Maupoil, V.; Cosnay, P.; Findlay, I. Catecholaminergic automatic activity in the rat pulmonary vein: Electrophysiological differences between cardiac muscle in the left atrium and pulmonary vein. Am. J. Physiol. Heart. Circ. Physiol. 2009, 297, 102-108. [CrossRef]

10. Lipp, P.; Laine, M.; Tovey, S.C.; Burrell, K.M.; Berridge, M.J.; Li, W.; Bootman, M.D. Functional InsP3 receptors that may modulate excitation-contraction coupling in the heart. Curr. Biol. 2000, 10, 939-942. [CrossRef]

11. Mackenzie, L.; Bootman, M.D.; Laine, M.; Berridge, M.J.; Thuring, J.; Holmes, A.; Li, W.H.; Lipp, P. The role of inositol 1,4,5-trisphosphate receptors in $\mathrm{Ca}^{2+}$ signalling and the generation of arrhythmias in rat atrial myocytes. J. Physiol. 2002, 541, 395-409. [CrossRef] [PubMed]

12. Jones, G.; Spencer, B.D.; Adeniran, I.; Zhang, H. Development of biophysically detailed electrophysiological models for pacemaking and non-pacemaking human pulmonary vein cardiomyocytes. Conf Proc. IEEE Eng. Med. Biol. Soc. 2012, 2012, 199-202. [PubMed]

13. Seol, C.A.; Kim, J.; Kim, W.T.; Ha, J.M.; Choe, H.; Jang, Y.J.; Shim, E.B.; Youm, J.B.; Earm, Y.E.; Leem, C.H. Simulation of spontaneous action potentials of cardiomyocytes in pulmonary veins of rabbits. Prog. Biophys. Mol. Biol. 2008, 96, 132-151. [CrossRef] [PubMed]

14. Hinch, R. A mathematical analysis of the generation and termination of calcium sparks. Biophys. J. 2004, 86, 1293-1307. [CrossRef]

15. Hinch, R.; Greenstein, J.L.; Tanskanen, A.J.; Xu, L.; Winslow, R.L. A simplified local control model of calcium-induced calcium release in cardiac ventricular myocytes. Biophys. J. 2004, 87, 3723-3736. [CrossRef] [PubMed]

16. Himeno, Y.; Asakura, K.; Cha, C.Y.; Memida, H.; Powell, T.; Amano, A.; Noma, A. A human ventricular myocyte model with a refined representation of excitation-contraction coupling. Biophys. J. 2015, 109, 415-427. [CrossRef] [PubMed]

17. Cooling, M.; Hunter, P.; Crampin, E.J. Modeling hypertrophic IP3 transients in the cardiac myocyte. Biophys. J. 2007, 93, 3421-3433. [CrossRef]

18. Saucerman, J.J.; Brunton, L.L.; Michailova, A.P.; McCulloch, A.D. Modeling beta-adrenergic control of cardiac myocyte contractility in silico. J. Biol. Chem. 2003, 278, 47997-48003. [CrossRef] [PubMed]

19. Ferrier, G.R. The effects of tension on acetylstrophanthidin-induced transient depolarizations and aftercontractions in canine myocardial and Purkinje tissues. Circ. Res. 1976, 38, 156-162. [CrossRef]

20. Aronson, R.S.; Gelles, J.M. The effect of ouabain, dinitrophenol, and lithium on the pacemaker current in sheep cardiac Purkinje fibers. Circ. Res. 1977, 40, 517-524. [CrossRef]

21. Kass, R.S.; Tsien, R.W.; Weingart, R. Ionic basis of transient inward current induced by strophanthidin in cardiac Purkinje fibres. J. Physiol. 1978, 281, 209-226. [CrossRef] [PubMed]

22. Matsuda, H.; Noma, A.; Kurachi, Y.; Irisawa, H. Transient depolarization and spontaneous voltage fluctuations in isolated single cells from guinea pig ventricles. Calcium-mediated membrane potential fluctuations. Circ. Res. 1982, 51, 142-151. [CrossRef]

23. Ter Keurs, H.E.; Boyden, P.A. Calcium and arrhythmogenesis. Physiol. Rev. 2007, 87, 457-506. [CrossRef] 
24. Cha, C.Y.; Santos, E.; Amano, A.; Shimayoshi, T.; Noma, A. Time-dependent changes in membrane excitability during glucose-induced bursting activity in pancreatic beta cells. J. Gen. Physiol. 2011, 138, 39-47. [CrossRef] [PubMed]

25. Takeda, Y.; Shimayoshi, T.; Holz, G.G.; Noma, A. Modeling analysis of inositol 1,4,5-trisphosphate receptor-mediated $\mathrm{Ca}^{2+}$ mobilization under the control of glucagon-like peptide- 1 in mouse pancreatic beta-cells. Am. J. Physiol. Cell. Physiol. 2016, 310, 337-347. [CrossRef]

26. Kurata, Y.; Tsumoto, K.; Hayashi, K.; Hisatome, I.; Tanida, M.; Kuda, Y.; Shibamoto, T. Dynamical mechanisms of phase-2 early afterdepolarizations in human ventricular myocytes: Insights from bifurcation analyses of two mathematical models. Am. J. Physiol. Heart Circ. Physiol. 2017, 312, 106-127. [CrossRef] [PubMed]

27. Shimoni, Y.; Severson, D.; Giles, W. Thyroid status and diabetes modulate regional differences in potassium currents in rat ventricle. J. Physiol. 1995, 488, 673-688. [CrossRef]

28. Shinagawa, Y.; Satoh, H.; Noma, A. The sustained inward current and inward rectifier K+ current in pacemaker cells dissociated from rat sinoatrial node. J. Physiol. 2000, 523, 593-605. [CrossRef]

29. Severs, N.J.; Slade, A.M.; Powell, T.; Twist, V.W.; Warren, R.L. Correlation of ultrastructure and function in calcium-tolerant myocytes isolated from the adult rat heart. J. Ultrastruct. Res. 1982, 81, 222-239. [CrossRef]

30. Volders, P.G.; Vos, M.A.; Szabo, B.; Sipido, K.R.; de Groot, S.H.; Gorgels, A.P.; Wellens, H.J.; Lazzara, R. Progress in the understanding of cardiac early afterdepolarizations and torsades de pointes: Time to revise current concepts. Cardiovasc. Res. 2000, 46, 376-392. [CrossRef]

31. Alfonzo-Mendez, M.A.; Carmona-Rosas, G.; Hernandez-Espinosa, D.A.; Romero-Avila, M.T.; Garcia-Sainz, J.A. Different phosphorylation patterns regulate alpha1D-adrenoceptor signaling and desensitization. Biochim. Biophys. Acta. Mol. Cell. Res. 2018, 1865, 842-854. [CrossRef] [PubMed]

32. Garcia-Sainz, J.A.; Vazquez-Prado, J.; del Carmen Medina, L. Alpha 1-adrenoceptors: Function and phosphorylation. Eur. J. Pharm. 2000, 389, 1-12. [CrossRef]

33. Rajagopal, S.; Shenoy, S.K. GPCR desensitization: Acute and prolonged phases. Cell. Signal 2018, 41, 9-16. [CrossRef] [PubMed]

34. Abdellatif, M.M.; Neubauer, C.F.; Lederer, W.J.; Rogers, T.B. Angiotensin-induced desensitization of the phosphoinositide pathway in cardiac cells occurs at the level of the receptor. Circ. Res. 1991, 69, 800-809. [CrossRef] [PubMed]

35. Jiang, T.; Pak, E.; Zhang, H.L.; Kline, R.P.; Steinberg, S.F. Endothelin-dependent actions in cultured AT-1 cardiac myocytes. The role of the epsilon isoform of protein kinase C. Circ. Res. 1996, 78, 724-736. [CrossRef] [PubMed]

36. Zhang, S.; Hiraoka, M.; Hirano, Y. Effects of alpha1-adrenergic stimulation on L-type Ca2+ current in rat ventricular myocytes. J. Mol. Cell. Cardiol. 1998, 30, 1955-1965. [CrossRef] [PubMed]

37. Terzic, A.; Puceat, M.; Clement, O.; Scamps, F.; Vassort, G. Alpha 1-adrenergic effects on intracellular pH and calcium and on myofilaments in single rat cardiac cells. J. Physiol. 1992, 447, 275-292. [CrossRef]

38. Miki, K.; Yoshimoto, M. Sympathetic nerve activity during sleep, exercise, and mental stress. Auton. Neurosci. 2013, 174, 15-20. [CrossRef]

39. Hartmann, H.A.; Mazzocca, N.J.; Kleiman, R.B.; Houser, S.R. Effects of phenylephrine on calcium current and contractility of feline ventricular myocytes. Am. J. Physiol. 1988, 255, 1173-1180. [CrossRef]

40. Hescheler, J.; Nawrath, H.; Tang, M.; Trautwein, W. Adrenoceptor-mediated changes of excitation and contraction in ventricular heart muscle from guinea-pigs and rabbits. J. Physiol. 1988, 397, 657-670. [CrossRef]

41. Ertl, R.; Jahnel, U.; Nawrath, H.; Carmeliet, E.; Vereecke, J. Differential electrophysiologic and inotropic effects of phenylephrine in atrial and ventricular heart muscle preparations from rats. Naunyn. Schmiedebergs Arch. Pharm. 1991, 344, 574-581. [CrossRef]

42. Jahnel, U.; Duwe, E.; Pfennigsdorf, S.; Nawrath, H. On the mechanism of action of phenylephrine in rat atrial heart muscle. Naunyn Schmiedebergs Arch. Pharm. 1994, 349, 408-415. [CrossRef]

43. Schumann, H.J.; Wagner, J.; Knorr, A.; Reidemeister, J.C.; Sadony, V.; Schramm, G. Demonstration in human atrial preparations of alpha-adrenoceptors mediating positive inotropic effects. Naunyn Schmiedebergs Arch. Pharm. 1978, 302, 333-336. [CrossRef]

44. Skomedal, T.; Aass, H.; Osnes, J.B.; Fjeld, N.B.; Klingen, G.; Langslet, A.; Semb, G. Demonstration of an alpha adrenoceptor-mediated inotropic effect of norepinephrine in human atria. J. Pharm. Exp. 1985, 233, 441-446. 
45. Wang, Y.G.; Dedkova, E.N.; Ji, X.; Blatter, L.A.; Lipsius, S.L. Phenylephrine acts via IP3-dependent intracellular NO release to stimulate L-type Ca2+ current in cat atrial myocytes. J. Physiol 2005, 567, 143-157. [CrossRef] [PubMed]

46. Jahnel, U.; Jakob, H.; Nawrath, H. Electrophysiologic and inotropic effects of alpha-adrenoceptor stimulation in human isolated atrial heart muscle. Naunyn Schmiedebergs Arch. Pharm. 1992, 346, 82-87. [CrossRef]

47. Asakura, K.; Cha, C.Y.; Yamaoka, H.; Horikawa, Y.; Memida, H.; Powell, T.; Amano, A.; Noma, A. EAD and DAD mechanisms analyzed by developing a new human ventricular cell model. Prog. Biophys. Mol. Biol. 2014, 116, 11-24. [CrossRef]

48. Song, Y.; Hao, G.; Boyett, M.; Yang, X.; Du, Y.; Shui, Z. Action potential, sodium and gap junction channels in rat pulmonary vein myocytes. Proc. Physiol. Soc. 2009, 15.

49. Boyle, W.A.; Nerbonne, J.M. Two functionally distinct 4-aminopyridine-sensitive outward K+ currents in rat atrial myocytes. J. Gen. Physiol. 1992, 100, 1041-1067. [CrossRef]

50. Pond, A.L.; Scheve, B.K.; Benedict, A.T.; Petrecca, K.; Van Wagoner, D.R.; Shrier, A.; Nerbonne, J.M. Expression of distinct ERG proteins in rat, mouse, and human heart. Relation to functional $\mathrm{I}_{\mathrm{Kr}}$ channels. J. Biol. Chem. 2000, 275, 5997-6006. [CrossRef]

51. Pandit, S.V.; Clark, R.B.; Giles, W.R.; Demir, S.S. A mathematical model of action potential heterogeneity in adult rat left ventricular myocytes. Biophys. J. 2001, 81, 3029-3051. [CrossRef]

52. Bondarenko, V.E.; Szigeti, G.P.; Bett, G.C.; Kim, S.J.; Rasmusson, R.L. Computer model of action potential of mouse ventricular myocytes. Am. J. Physiol. Heart Circ. Physiol. 2004, 287, 1378-1403. [CrossRef] [PubMed]

53. Kuzumoto, M.; Takeuchi, A.; Nakai, H.; Oka, C.; Noma, A.; Matsuoka, S. Simulation analysis of intracellular $\mathrm{Na}^{+}$and $\mathrm{Cl}^{-}$homeostasis during $\beta 1$-adrenergic stimulation of cardiac myocyte. Prog. Biophys. Mol. Biol. 2008, 96, 171-186. [CrossRef] [PubMed]

54. Himeno, Y.; Sarai, N.; Matsuoka, S.; Noma, A. Ionic mechanisms underlying the positive chronotropy induced by beta1-adrenergic stimulation in guinea pig sinoatrial node cells: A simulation study. J. Physiol. Sci. 2008, 58, 53-65. [CrossRef]

55. Oka, C.; Cha, C.Y.; Noma, A. Characterization of the cardiac $\mathrm{Na}+\mathrm{K}+$ pump by development of a comprehensive and mechanistic model. J. Biol. 2010, 265, 68-77. [CrossRef] [PubMed]

56. Smith, N.P.; Crampin, E.J. Development of models of active ion transport for whole-cell modelling: Cardiac sodium-potassium pump as a case study. Prog. Biophys. Mol. Biol. 2004, 85, 387-405. [CrossRef] [PubMed]

57. Despa, S.; Bossuyt, J.; Han, F.; Ginsburg, K.S.; Jia, L.G.; Kutchai, H.; Tucker, A.L.; Bers, D.M. Phospholemmanphosphorylation mediates the beta-adrenergic effects on $\mathrm{Na} / \mathrm{K}$ pump function in cardiac myocytes. Circ. Res. 2005, 97, 252-259. [CrossRef]

58. Tran, K.; Smith, N.P.; Loiselle, D.S.; Crampin, E.J. A thermodynamic model of the cardiac sarcoplasmic/endoplasmic Ca ${ }^{2+}$ (SERCA) pump. Biophys. J. 2009, 96, 2029-2042. [CrossRef]

59. Miyakawa, T.; Maeda, A.; Yamazawa, T.; Hirose, K.; Kurosaki, T.; Iino, M. Encoding of $\mathrm{Ca}^{2+}$ signals by differential expression of IP3 receptor subtypes. EMBO J. 1999, 18, 1303-1308. [CrossRef]

60. Sneyd, J.; Dufour, J.F. A dynamic model of the type-2 inositol trisphosphate receptor. Proc. Natl. Acad. Sci. USA 2002, 99, 2398-2403. [CrossRef]

61. Jahnel, U.; Nawrath, H.; Carmeliet, E.; Vereecke, J. Depolarization-induced influx of sodium in response to phenylephrine in rat atrial heart muscle. J. Physiol. 1991, 432, 621-637. [CrossRef] [PubMed]

62. Ermentrout, B. Simulating, Analyzing, and Animating Dynamical Systems: A Guide to XPPAUT for Researchers and Students. Software. Environments and Tools; Society for Industrial and Applied Mathematics SIAM: Philadelphia, PA, USA, 2002.

63. Yan, D.H.; Ishihara, K. Two Kir2.1 channel populations with different sensitivities to $\mathrm{Mg}^{2+}$ and polyamine block: A model for the cardiac strong inward rectifier $\mathrm{K}^{+}$channel. J. Physiol. 2005, 563, 725-744. [CrossRef] [PubMed]

(C) 2019 by the authors. Licensee MDPI, Basel, Switzerland. This article is an open access article distributed under the terms and conditions of the Creative Commons Attribution (CC BY) license (http://creativecommons.org/licenses/by/4.0/). 